\title{
KIERUNKI AKTYWIZACJI ZAWODOWEJ KOBIET W GALICJI W KOŃCU XIX I NA POCZACTKU XX WIEKU W ŚWIETLE SPISÓW LUDNOŚCI
}

Szczepan Kozak

Uniwersytet Rzeszowski

\author{
ABSTRACT \\ TRENDS IN THE VOCATIONAL DEVELOPMENT OF WOMEN IN \\ GALICIA IN THE LATE $19^{\text {TH }}$ AND EARLY $20^{\text {TH }}$ CENTURY IN THE LIGHT \\ OF POPULATION CENSUSES
}

Although the question of women's vocational development in Galicia has been studied from many scholarly perspectives, it was rarely a subject of separate studies. In the presented article the author deals with main trends in women's vocational development and with features that characterized the process of women's gaining the labor market in the years 1880-1910. On the basis of the results of Austrian censuses published in both main all-Austrian and provincial periodicals, it was possible to state that women's vocational development was of a traditional character. Little participation in that phenomenon belonged to the non-agricultural sector. In comparison to other Polish regions as well as to those of Austrian crown lands Galicia appears to have been very poor and unfavorable. (Trans.: Antoni Sarkady)

Key words: Galicia, woman, labor, vocational structure in the $19^{\text {th }} \mathrm{c}$.

Stowa kluczowe: Galicja, kobieta, praca, struktura zawodowa w XIX wieku.

Kwestia aktywności zawodowej kobiet w XIX wieku na ziemiach polskich, a w Galicji w szczególności, znajduje swoje odzwierciedlenie w obszarze co najmniej trzech pól badawczych. Mam tu na myśli opracowania poświęcone ewolucji struktury zawodowej, historii kobiet oraz wybranym grupom zawodowym. 
W najbardziej znanych pracach dotyczących struktury zawodowej ludności zaboru austriackiego autorstwa między innymi Jadwigi Kłapkowskiej ${ }^{1}$, Tomasza Gąsowskiego ${ }^{2}$, po części Anny Żarnowskiej ${ }^{3}$ czy Piotra Korysia i Macieja Tymińskiego ${ }^{4}$ wątek kobiecy był jednak eksponowany marginalnie ${ }^{5}$.

Najwięcej miejsca tematyka ta zajmowała - co oczywiste - w publikacjach z zakresu historii kobiet, przy czym autorzy tych opracowań zwracali uwagę na szeroko rozumianą stronę społeczną problemu zatrudnienia (ramy prawne, warunki i specyfika pracy, przełamywanie barier itp.), traktując go jako jeden z elementów kwestii kobiecej, obok dostępu do wykształcenia, praw wyborczych czy rewizji prawa cywilnego. Wyrazem tych ogólnych zainteresowań w powojennej historiografii są publikacje Walentyny Najdus ${ }^{6}$, Bogusławy Czajeckiej ${ }^{7}$, Lidii A. Zyblikiewicz ${ }^{8}$, Szczepana Kozaka ${ }^{9}$, Ryszarda Tomczyka ${ }^{10} \mathrm{i}$ kilku innych autorów ${ }^{11}$. Nie dają one jednak pełnego obrazu aktywizacji zawodowej, poprzestając na analizie konkretnego zjawiska (np. bizneswoman) albo ograniczając się do wybranej populacji mieszkańców ${ }^{12}$. W wielu

1 J. Kłapkowska, Struktura zawodowa ludności Galicji w erze autonomicznej, „Prace Prawnicze. ZNUJ" 1975, nr 70, s. 115-131.

2 T. Gąs ow ski, Struktura społeczno-zawodowa mieszkańców większych miast galicyjskich w okresie autonomicznym, „Prace Historyczne. ZNUJ” 1997, z. 123, s. 113-135.

A. Żarnowska, Kierunki ewolucji struktury społeczno-zawodowej na ziemiach polskich i jej odmienności dzielnicowe w końcu XIX i na poczatku XX w. [w:] Drogi integracji spoleczeństwa w Polsce $X I X-X X$ w., red. H. Zieliński, Wrocław [etc.] 1976, s. 139-150; eadem, Zmiany struktury społeczno-zawodowej ludności ziem polskich na tle Europy Środkowej [w:] Gospodarka przemystowa i poczatki cywilizacji technicznej. Studia i materiaty, red. I. Pietrzak-Pawłow ska, Wrocław 1977, s. 257-269.

4 P. Koryś, M. Tymiński, Struktura zawodowa ziem polskich na przetomie XIX i XX w., „Roczniki Dziejów Społecznych i Gospodarczych" 2015, t. 75, s. 129-166.

5 Zob. K. Broński, Rozwój gospodarczy większych miast galicyjskich w okresie autonomii, Kraków 2003, s. 89-98; idem, Struktura społeczno-zawodowa oraz sytuacja ekonomiczna ludności większych miast galicyjskich dobie autonomii (1867-1914), „Zeszyty Naukowe Akademii Ekonomicznej w Krakowie" 2003, nr 638, s. 5-20.

6 W. Najdu s, Zmiany społeczno-ekonomicznej pozycji kobiety w galicyjskim środowisku drobnomieszczańskim [w:] Kobieta i edukacja na ziemiach polskich w XIX i XX w. Zbiór studiów. Cz. 2, red. A. Żarnowska, A. Szwarc, Warszawa 1992, s. 237-256.

7 B. Czajecka, Z domu w szeroki świat. Droga kobiet do niezależności w zaborze austriackim w latach 1890-1914, Kraków 1990.

8 L.A.Zyblikiewicz, Kobieta w Krakowie z 1880 r. w świetle ankiet powszechnego spisu ludności. Studium demograficzne, Kraków 1999; eadem, Aktywność zawodowa kobiet w Krakowie w II połowie XIX wieku, „Przeszłość Demograficzna Polski” 2015, t. 37, nr 4, s. 83-103.

9 Sz. Kozak, Kobieta na prowincji galicyjskiej w świetle akt notarialnych 1871-1914. Studium historyczno-źródtoznawcze, Rzeszów 2013.

10 R. Tomczyk, Rusinki (Ukrainki) w austriackiej Galicji. Pomiędzy konserwatyzmem a radykalizmem, „Przegląd Zachodniopomorski” 2012 nr 2, s. 107-109.

11 Szerzej na temat stanu badań zob. Sz. Kozak, Kobiety w życiu gospodarczym Galicji. Stan i perspektywy badań [w:] Region i regionalizm w archeologii i historii, red. J. Hoff, S. Kadrow, Rzeszów 2013, s. 174-183.

12 Sz. Kozak, Aktywność gospodarcza kobiet w Galicji w świetle Skorowidza przemystowo-handlowego z 1912 roku. Zarys problematyki, „Studia z Historii Społeczno-Gospodarczej XIX i XX wieku" 2014, t. 13, s. 81-95; L.A. Zyblikiewicz, Aktywność zawodowa kobiet.... Szersza literatura na ten temat zob. bibliografia w: Sz. Kozak, Kobiety w życiu... 
przypadkach zatrzymywano się na charakterystyce pojedynczych grup społecznych czy zawodów, zwłaszcza takich, w których reprezentatywność kobiet była bardzo wyraźna, ewentualnie na tak zwanych profesjach typowo kobiecych bądź przypadkach wyjątkowych. Osobny wątek stanowią badania nad dziejami kobiet ze społeczności ukraińskiej, ale i w tym przypadku zainteresowanie ich aktywizacją zawodową miało charakter drugoplanowy ${ }^{13}$.

Trzeci nurt reprezentują prace poświęcone wybranym działom gospodarki. Jako przykład warto tu wymienić badania Andrzeja Burzyńskiego dotyczące przemysłu ciężkiego ${ }^{14}$. Należy podkreślić, że autor różnicuje przedmiot swoich zainteresowań, osobno zajmując się również zatrudnieniem kobiet wśród robotników przemysłowych.

Podsumowując, we współczesnej historiografii brakuje monograficznego ujęcia problemu aktywizacji zawodowej kobiet, aczkolwiek na wielu płaszczyznach jest on dostrzegalny. Dużo miejsca wypełnia tematyka uwarunkowań prawnych, specyfiki pracy kobiet z poszczególnych grup społecznych, ich rola w sektorze edukacji, a nawet kwestia ruchu stowarzyszeniowego ${ }^{15}$. Ta słuszna skądinąd optyka ukazywała rozliczne nierówności i towarzyszącą im dyskryminację. Pomimo to trudno dzisiaj znaleźć w tych publikacjach jednoznaczną odpowiedź na pytanie, jaka część kobiet partycypowała w galicyjskim rynku pracy, jakie trendy rozwojowe charakteryzowały

13 Por. z nowszych prac: I. Czerczowy cz, Realizacja zawodowa kobiet końca XIX-poczatku XXw. Na przykładzie społeczeństwa ukraińskiego w Galicji, „Przegląd Nauk Historycznych” 2014, 13 (2), s. 147-161; eadem, ,Zdrowa, niemoralna, bez najmniejszego wyksztalcenia”. Kobiety w sprawach karnych na podstawie dokumentów Sądu Krajowego we Lwowie (druga połowa XIX - poczatek XX wieku) [w:] Kobieta w Galicji. Nowoczesność i tradycja, red. J. Kamińska-Kwak, Sz. Kozak, D. Opaliński, Rzeszów 2016, s. 100-109; eadem, Społeczna wizja życia codziennego kobiety Ukrainki we Lwowie na przełomie XIX i XX wieku [w:] Lwów. Miasto - społeczeństwo - kultura, t. 9: Życie codzienne miasta, red. K. Karolczak, Ł.T. Sroka, Kraków 2014, s. 244-254; eadem, Ukrainki w Galicji Wschodniej $w$ drugiej połowie XIX - na początku XX wieku. Między tradycyjnymi wartościami rodzinnymi a wyzwaniami emancypacji [w:] Obrazy kobiecości. Zbiór studiów, red. M. Jabłońs ki, B. Koperski, J. Falla, W. Pilch, M. Hohenauer, Kraków 2014, s. 227-242; M. Baidak, Between society and house: The history of the emancipation of the Ukrainian women of Eastern Galicia during the First World War, ,Res Gestae. Czasopismo Historyczne" 2016 (3), s. 194-235. DOI: 10.24917/24504475.3.8; еаdem, Жінка в Галичині в умовах першої світової війни у світлі порівняльних студій [w:] Kobieta w Galicji. Nowoczesność i tradycja, s. 494-507; I. Орлевич, Жіноче питання у трактуванні русофілів (за сторінками періодичного видання «Временникь Ставропигійскаго Института») [w:] Kobieta w Galicji. Nowoczesność i tradycja, s. 57-72; Н. Ко л б, Роль жінки (матері / дружини) в житті грекокатолицького парафіяльного духовенства в Галичині наприкінці XIX - на початку XX століття (на прикладі о. Ісидора Глинського) [w:] Kobieta w Galicji. Nowoczesność i tradycja, s. 195-209; O. Hanusyn, ,Inteligentna kobieta nasza czuła się jednocześnie Rusinka i mężczyzna””. Wątki kobiece w ksztaltowaniu się ukraińskiej inteligencji w dziewiętnastowiecznej Galicji [w:] Kobieta w Galicji. Nowoczesność i tradycja, s. 110-120.

14 A. Burzyński, Robotnicy w przemyśle ciężkim w Galicji w dobie autonomicznej. Struktura zatrudnienia, Wrocław [etc.] 1985.

15 Szersza literatura zob. bibliografia w: Sz. Kozak, Kobieta w Galicji. Problemy metodologiczne badań, ich dotychczasowy dorobek i postulaty na przyszłość [w:] Galicja 1772-1918. Problemy metodologiczne, stan i potrzeby badań, t. 1, red. A. Kawalec, W. Wierzbieniec, L. Zaszkilniak, Rzeszów 2011, s. 244-248. 
to zjawisko i czym wyróżniała się sytuacja kobiet w Galicji na tle pozostałych ziem. Podejmowane przy tej okazji próby generalizacji kończyły się przeważnie przyjmowaniem zmiennego punktu odniesienia, który raz stanowiła grupa czynnych zawodowo, kiedy indziej pracownicy samodzielni lub jakaś kategoria nadrzędna. Wyjątkiem są badania L.A. Zyblikiewicz dotyczące ludności Krakowa ${ }^{16}$ czy Joanny Kordzikowskiej analizującej sytuację kobiet w Rzeszowie (również w aspekcie pracy zawodowej) na podstawie ankiet spisowych ${ }^{17}$.

Celem niniejszego artykułu jest odnalezienie głównych cech aktywizacji mieszkanek Galicji przez pryzmat ewolucji, jakiej podlegała ich struktura zawodowa w latach 1880-1910. Przyjęte cezury chronologiczne wynikały z uwarunkowań źródłowych oraz zmieniającej się sytuacji społeczno-ekonomicznej. Koniec XIX i początek XX wieku to okres, w którym należałoby oczekiwać przynajmniej pewnych symptomów wskazujących na kształtowanie się nowoczesnego społeczeństwa. Proces ten przebiegał nierównomiernie, owocując powstaniem różnic nawet w obrębie samej Galicji. U schyłku XIX wieku ludność utrzymująca się z sektora pozarolniczego nie przekraczała w tej prowincji jednej czwartej ogółu, na Górnym Śląsku było to $61 \%$, w Królestwie Polskim, podobnie jak w Poznańskiem i na Pomorzu $-42 \%{ }^{18}$. Historycy zauważają, że na przełomie XIX i XX wieku kształt struktury społeczno-zawodowej ludności wszystkich ziem polskich jeszcze w niewielkim stopniu upodabniał się do krajów uprzemysławiających się. Najlepiej wypadły tu obszary zaboru pruskiego i część Królestwa Polskiego ${ }^{19}$. Pomimo to znajdujemy opinie o znacznej dynamice rozwojowej grup typowych dla takich społeczeństw, a w szczególności robotników przemysłowych ${ }^{20}$. Pod tym względem Galicja należała do obszarów słabo rozwiniętych, choć nowsze badania wskazują, że dystans dzielący ją od pozostałych ziem polskich nie był aż tak duży ${ }^{21}$. Istotne wydaje się więc pytanie, jak w tych warunkach kształtowała się perspektywa kobiet chcących podjąć pracę.

Za podstawę rozważań przyjęto wyniki spisów ludności z lat 1880-1910 opublikowane na łamach „Rocznika Statystyki Przemysłu i Handlu Krajowego” oraz „Österreichische Statistik” (w latach 1882-1916)22. Wcześniejsze materiały nie za-

16 L.A. Zyblikiewicz, Ludność Krakowa w drugiej połowie XIX wieku. Struktura demograficzna, zawodowa i społeczna, Kraków 2014.

17 J. Kordzikowska, Sytuacja społeczno-zawodowa kobiety w Rzeszowie pod koniec XIX wieku, mps rozprawy doktorskiej, Rzeszów 2012.

18 A. Żarnowska, Zmiany struktury..., s. 259 (tabela 39); P. Koryś, M. Tymiński, op. cit., s. 157 (tabela 3, wykres 9).

19 P. Koryś, M. Tymiński, op. cit., s. 159.

20 A. Żarnowska, Zmiany struktury..., s. 268.

21 P. Koryś, M. Tymiński, op. cit., s. 159.

22 Dane do analizy struktury zawodowej w Galicji zaczerpnięto z: RSPHK 1888, z. 11; OS 1894, 33. Band, 11. Heft; OS 1904, 66. Band, 11. Heft; OS.NF 1916, 3. Band, 10. Heft. Do analiz porównawczych wykorzystano: OS.NF 1914, 3. Band, 2. Heft (Niederösterreich); OS.NF 1914, 3. Band, 3. Heft (Oberösterreich und Salzburg); OS.NF 1915, 3. Band, 4. Heft (Steiermark); OS.NF 1915, 3. Band, 5. Heft (Kärnten und Krain); OS.NF 1915, 3. Band, 6. Heft (Küstenland und Dalmatien); OS.NF 1915, 3. Band, 7. Heft (Tirol und Vorarlberg); OS.NF 1916, 3. Band, 8. Heft (Böhmen); OS.NF 1916, 3. Band, 9. Heft (Mähren und Schlesien). 
wierały wystarczającego zestawu danych. Choć źródło to dość wcześnie zdyskredytował między innymi Franciszek Bujak, pisząc, że struktura zatrudnienia „,...] jest przy spisach ludności ubocznie traktowana, toteż jej rezultatów zbyt ściśle brać nie należy" ${ }^{\prime 2}$, nie można przejść obok tak masowego materiału obojętnie, zważywszy na ograniczoną dostępność ankiet spisowych. Wiarygodność austriackich spisów powszechnych znalazła swoje odzwierciedlenie również w nowszej literaturze, dlatego ta tematyka nie będzie przedmiotem analiz tego artykułu ${ }^{24}$. Ocena, jakiej ankiety spisowe się doczekały, nie wyeliminowała ich z warsztatu historyka, aczkolwiek w przypadku danych dotyczących kobiet wypada słabiej. Krytycy podają w wątpliwość między innymi procedurę, a w tym postawę osób odpowiedzialnych za przeprowadzanie spisów, często niedostrzegających tożsamości zawodowej kobiety ${ }^{25}$. W wersji publikowanej prezentacja wyników różni się między sobą zakresem grupowania. Każdy rocznik reprezentuje pod tym względem inną jakość, co widać na przykładzie zmieniającej się w kolejnych latach liczby ogólnych kategorii zawodowych, ich wewnętrznego rozwarstwienia czy podziału ludności według stosunku pracy. Jeśli chodzi o dane na temat zatrudnienia kobiet, należy podkreślić, że statystyki państwowe zdecydowanie górują nad krajowymi, które uwzględniają strukturę płciową w relacji do wykonywanego zawodu bardzo wybiórczo. Najbardziej szczegółowe wydają się tomy „Österreichische Statistik” publikujące wyniki spisów z lat 1900 i 1910. Zawierają one dane o zatrudnieniu kobiet i mężczyzn z uwzględnieniem podziału administracyjnego (izby handlowe, powiaty), wieku (przedziały dziesięcioi pięcioletnie) oraz w nieco ograniczony sposób wyznania i języka (w 1910 r.). Próbując jednak uzyskać jakikolwiek obraz zatrudnienia, należy statystyki te częściowo skorygować. Na wykresie 1 przedstawiono rozkład głównych grup ludności w poszczególnych latach. Początkowo spisy powszechne dzieliły mieszkańców Galicji na zarobkujących i niezarobkujących. Dopiero od 1900 roku osobno wyodrębniono pomagających członków rodziny. Biorąc pod uwagę roczniki 1880 i 1890, można domniemywać, że osoby te, a przynajmniej znaczną ich część, zaliczono wówczas do zarobkujących. Przemawia za tym wyraźny spadek liczebności w obrębie osób uznanych za zarobkujące, obserwowalny w przekrojach od 1900 roku, pomimo że kategoria ta traktowana była w XIX wieku bardzo szeroko, z uwzględnieniem nie tylko aktywnych na rynku pracy, ale również posiadających jakiekolwiek źródło utrzymania (zob. aneks).

${ }_{23}$ F. Bujak, Galicja, t. 1, Warszawa 1908, s. 132.

24 Charakterystykę źródła przeprowadzili m.in.: A. Burzyński, Statystyka austriacka i krajowa jako źródło do badań nad struktura społeczno-zawodowa zatrudnionych w przemyśle ciężkim w Galicji, „Studia Historyczne” 1983, R. 26, z. 2 (101), s. 223-242; idem, Z rozważań nad ocena austriackich powszechnych spisów ludności z lat 1869-1919, „Przeszłość Demograficzna Polski” 1984, t. 15, s. 58-69; T. Gąsowski, Austriackie spisy ludności z lat 1869-1910, „Przeszłość Demograficzna Polski” 1981, t. 13, s. 37-48; K. Zamorski, Informator statystyczny do dziejów społeczno-gospodarczych Galicji. Ludność Galicji w latach 1857-1910, Kraków-Warszawa 1989; L.A. Zyblikiew icz, Powszechne spisy ludności w monarchii Habsburgów [w:] Celem nauki jest człowiek... Studia z historii społecznej i gospodarczej ofiarowane Helenie Madurowicz-Urbańskiej, red. P. Fran as zek, Kraków 2000, s. 387-400.

25 Por. W. Najdus, op. cit., s. 237-238. 


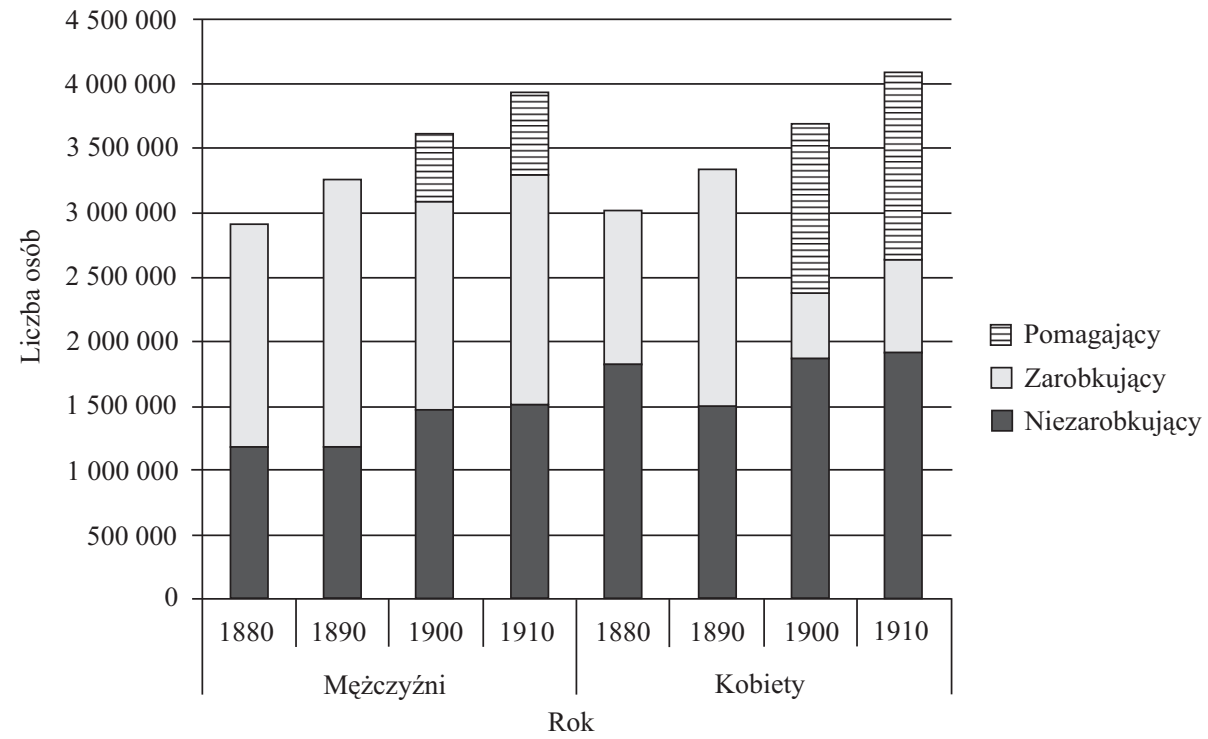

Wykres 1. Ludność Galicji pod względem aktywności zawodowej w latach 1880-1910

Źródło: obliczenia własne na podstawie: RSPHK 1888, z. 11; OS 1894, 33. Band, 11. Heft; OS 1904, 66. Band, 11. Heft; OS.NF 1916, 3. Band, 10. Heft.

Wątpliwości wzbudza nieproporcjonalnie duża liczba kobiet niezarobkujących w 1880 roku. Osoby obojga płci, nieposiadające żadnego źródła utrzymania stanowiły wówczas $50,40 \%$ całej populacji, a w kolejnych latach odpowiednio: $40,60 \%$ (1890), 45,68\% (1900) i 42,76\% (1910). Również udział kobiet w proporcji do mężczyzn, wśród niezarobkujących kształtujący się na poziomie $60,86 \% \mathrm{w} 1880 \mathrm{roku}$, w latach następnych nieco się obniżył - 55,89\% (1890), 56,10\% (1900) i 55,85\% (1910). Przypadki powyższe wskazują więc na możliwość przeszacowania. Utwierdza nas w tym porównanie z ludnością w wieku 0-14 lat (wykres 2) wyłączoną przynajmniej teoretycznie - z rynku pracy. Różnica w 1880 roku wynosi prawie jedną trzecią i dotyczy tylko kobiet. Nawet uzupełnienie o osoby w wieku $60+$ nie wyrównuje tych dysproporcji. Dokonując ekstrapolacji na podstawie przywołanych wyżej wskaźników z lat 1890-1910, można przyjąć, że liczba kobiet niezarobkujących w 1880 roku nie powinna być większa niż 1500 000. Wynikałoby z tego, że dane spisowe zawyżono co najmniej o $300000^{26}$.

26 Warto też zwrócić uwagę, że o podobną wielkość nie doszacowano z kolei liczby kobiet zatrudnionych w 1880 r. w sektorze rolniczym. Przyjmując taką argumentację, udział kobiet nieposiadających żadnego źródła utrzymania możemy oszacować w kolejnych latach na następującym poziomie: 51\% (1880), 45\% (1890), 51\% (1900) i 47\% (1900). Był to wynik wyższy od osiągniętego przez mężczyzn średnio o ok. 10 pkt proc. w zależności od roku spisowego. 


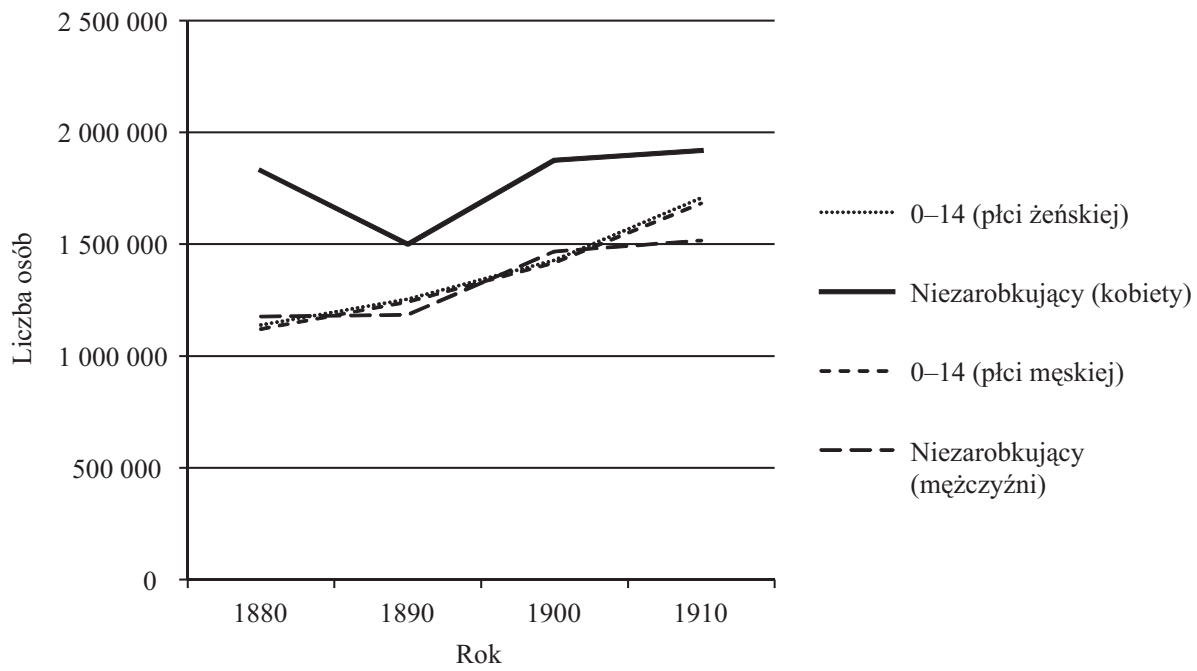

Wykres 2. Ludność niezarobkująca w Galicji w latach 1880-1910

Źródło: obliczenia własne na podstawie: RSPHK 1988, z. 11; OS 1894, 33. Band, 11. Heft; OS 1904, 66. Band, 11. Heft; OS.NF 1916, 3. Band, 10. Heft; oraz K. Zamorski, Informator statystyczny do dziejów spoteczno-gospodarczych Galicji. Ludność Galicji w latach 1857-1910, Kraków-Warszawa 1989, passim.

Aby ukazać obraz głównych elementów struktury zawodowej kobiet oraz porównać go z innymi regionami, wykorzystano metodę PST (Primary-Secondary-Tertiary). W ogólnym kształcie polega ona na zgrupowaniu poszczególnych kategorii zawodowych w trzech sektorach. Pierwszy (1) obejmuje rolnictwo i górnictwo (rozumiane jako pozyskiwanie surowców); drugi (2) - przemysł i rzemiosło; trzeci (3) - usługi, administrację publiczną, wolne zawody, służbę ${ }^{27}$. Na tym etapie do badań włączono razem osoby uznane w spisach za zatrudnione i pomagające. Wykluczono natomiast grupy nieproduktywne (rentierów, przebywających w zakładach opieki itp.). W zależności od rocznika i płci obejmowały one średnio 3\%, przy czym największe wartości osiągnęły w 1910 roku (kobiety - 6\%, mężczyźni - 4\%). Nie brano pod uwagę również armii. W ten sposób udało się oszacować udział kobiet pracujących w proporcji do pozostałych na: 49\% w 1880 roku, 54\% w 1890 roku, $\mathbf{4 8 \%}$ w 1900 roku i 50\% w 1910 roku. Wewnętrzne rozwarstwienie tej grupy uwzględniające wyodrębnione wcześniej obszary zaprezentowano na wykresie 3. 


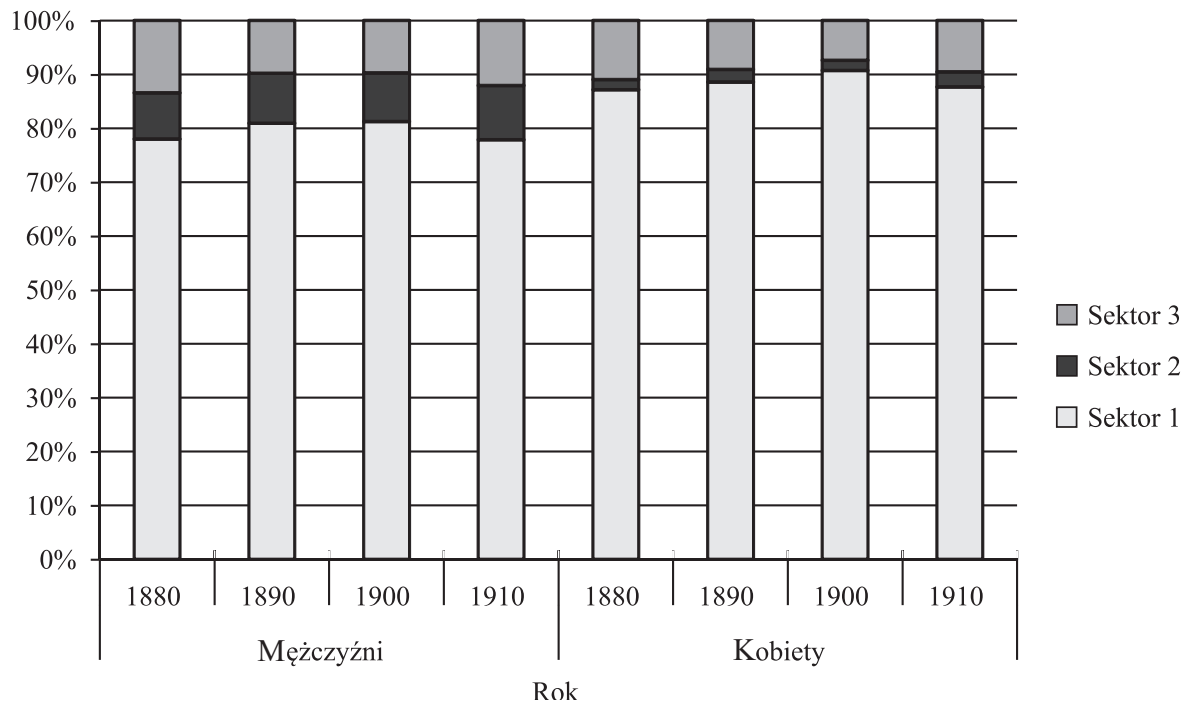

Wykres 3. Główne obszary aktywności zawodowej ludności Galicji w latach 1880-1910

Źródło: obliczenia własne na podstawie: RSPHK 1988, z. 11; OS 1894, 33. Band, 11. Heft; OS 1904, 66. Band, 11. Heft; OS.NF 1916, 3. Band, 10. Heft.

Mając na uwadze rozwój w czasie, nie dostrzeżono spektakularnych różnic między preferencjami zawodowymi osób obojga płci (wykres 3). Przez cały czas dominującym sektorem było rolnictwo. Dystans dzielący kobiety i mężczyzn wahał się w granicach 10 punktów procentowych, ale przy skali rzędu 80-90\% nie wydawało się to znaczącą dysproporcją. Co prawda zatrudnienie kobiet czerpiących swoje dochody z rolnictwa i wydobycia surowców aż do końca XIX wieku rosło, osiągając w 1900 roku 90\% (dla mężczyzn zatrzymało się już w 1890 r. na poziomie ok. 80\%), nie był to jednak wzrost znacząco zmieniający wcześniejsze proporcje. Dopiero w przedziale z 1910 roku pozycja rolnictwa nieznacznie osłabła, aczkolwiek w liczbach bezwzględnych ciągle dostrzegalna była tendencja wzrostowa.

Takie rozłożenie akcentów w gospodarce przez wiele lat nie sprzyjało modernizacji struktury zawodowej, a już na pewno nie stwarzało szerszej grupie kobiet nowych perspektyw zarobkowych. Nowsze badania pokazują jednak, że w okresie poprzedzającym I wojnę światową Galicja nosiła cechy tak zwanego regionu modernizującego $\operatorname{się}^{28}$. W kontekście braku czynnika, jakim jest industrializacja, za interesujące należy uznać teorię samomodernizacji oraz zjawiska zachodzące $\mathrm{w}$ większych miastach. Nie można wykluczyć, że pod wpływem tych przemian w początkach XX wie-

28 K. Broński, Galicja w dobie autonomii wobec wyzwań nowoczesności [w:] Między zacofaniem a modernizacją. Społeczno-gospodarcze problemy ziem polskich na przestrzeni wieków, red. E. Kościk, T. Głowiński, Wrocław 2009, s. 395-412; M. Kulczykowski, Modernizacja społeczeństwa galicyjskiego w warunkach autonomii politycznej [w:] Samomodernizacja społeczeństw w XIX wieku. Irlandczycy, Czesi, Polacy, red. L. Trzeciakowski, K. Makowski, Poznań 1999, s. 107-129. 
ku jakimś przekształceniom zaczął również ulegać rynek pracy. W większym stopniu ujawniły się efekty popularyzacji nowych gałęzi przemysłu (np. energetycznego), nie bez znaczenia zapewne był impuls w dziedzinie edukacji mającej na względzie podniesienie kwalifikacji zawodowych kobiet czy przewartościowania mentalnościowe. Wiadomo skądinąd, że w okresie tym nastąpiła ostrożna akceptacja ich aspiracji zawodowych, choć nie na wszystkich polach. Nieznaczny wzrost popularności przemysłu i rzemiosła w 1910 roku nie miał jednak wyraźnego wpływu na kształt całej struktury. Dla kobiet obszar ten odgrywał ciągle niewielką rolę (maksymalnie do $3 \%$ - por. wykres 3 ).

Marginalizacja decydujących o zaawansowaniu procesów modernizacyjnych sektorów pozarolniczych w ostrzejszej formie dotyczyła właśnie kobiet. W proporcji do mężczyzn ich udział wynosił w sektorze 2 zaledwie od 16\% (1880) do 20\% (1910). Dla porównania w rolnictwie i wydobyciu surowców relacje te kształtowały się przez cały badany okres niemal po połowie, w sektorze 3 zaś zatrudnienie kobiet nie spadło poniżej $40 \%$. Wiele do myślenia pozostawia jednak dynamika tego zatrudnienia. W sektorze przemysłowo-rzemieślniczym w porównaniu z 1880 rokiem wzrosło ono o ponad $100 \%$ (dla mężczyzn o ponad 50\%).

Główne trendy ewolucji struktury zatrudnienia w ramach poszczególnych sektorów pozarolniczych odzwierciedlają wykresy 4-6. W przypadku sektora rzemieślniczo-przemysłowego do końca XIX wieku bardzo wyraźna stała się dominacja dwóch działów - odzieżowego i spożywczego (wykres 4). Łącznie zatrudnienie znalazło tam ponad 77\% kobiet w 1890 i 80\% w 1900 roku. Podobnie musiało być również w 1880 roku, choć brak szczegółowych danych uniemożliwia weryfikację tej hipotezy. Dopiero w ostatnim z badanych przedziałów (1910) zauważamy zachwianie dotychczasowych proporcji, czego wyrazem staje się jeszcze większa dominacja przemysłu odzieżowego. Wyraźnie też widać, że zjawisko to objęło w największym stopniu subpopulację kobiet. Popularność tej formy zarobkowania wzrosła wśród nich z 40 do $60 \%$. W praktyce dynamika tego wzrostu była dość znacząca, ponieważ liczba kobiet zatrudnionych w branży odzieżowej w stosunku do lat poprzednich się podwoiła.

Inaczej wyglądała specyfika zatrudnienia mężczyzn, dla których sektor ten przypomnijmy - miał większe znaczenie. W 1910 roku jego zróżnicowanie okazało się bardziej proporcjonalne. Był on też w większym stopniu otwarty na inne gałęzie przemysłu, choć nie zawsze w przeszłości tak bywało. Jeszcze w 1890 roku preferencje zawodowe kobiet i mężczyzn, aczkolwiek w dostrzegalny sposób się różniły, to przejawiały zbliżoną tendencję przynajmniej w jednym - ponad połowa mężczyzn pracowała w przemyśle spożywczym i odzieżowym. W 1910 roku widać wzrost znaczenia przemysłu budowlanego, przetwórstwa metali i innych, przy spadku (o połowę) przemysłu spożywczego. Wtedy też różnice między uwarstwieniem zawodowym mężczyzn i kobiet były już bardzo głębokie.

W toku tej swoistej ewolucji kształtowały się dwie drogi aktywizacji zawodowej w obszarze przemysłu i rzemiosła: jedna, bardziej zachowawcza - w wersji dla kobiet; druga, będąca odbiciem procesów modernizacyjnych - dla mężczyzn. Właśnie w pierwszym dziesięcioleciu XX wieku drogi te wyraźnie się już rozeszły. 


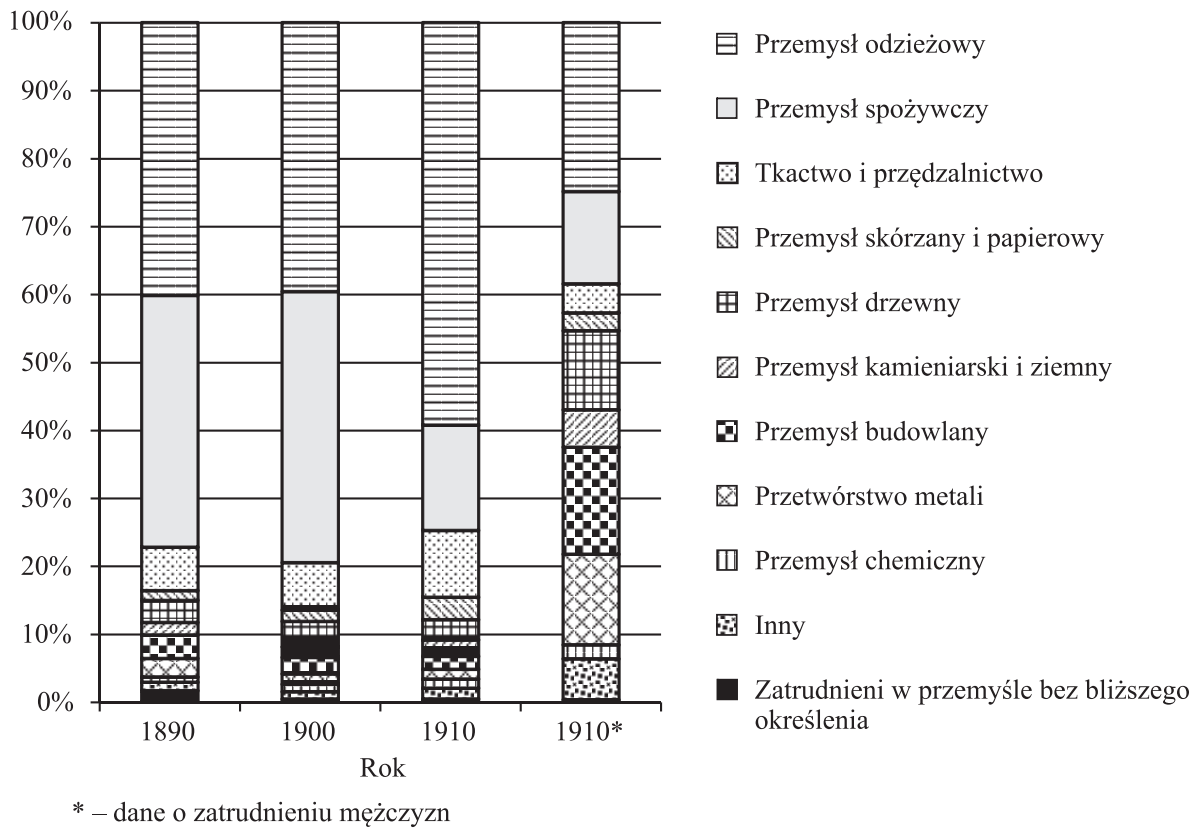

Wykres 4. Struktura zatrudnienia kobiet w sektorze rzemieślniczo-przemysłowym w latach $1890-1910$

Źródło: obliczenia własne na podstawie: RSPHK 1888, z. 11; OS 1894, 33. Band, 11. Heft; OS 1904, 66. Band, 11. Heft; OS.NF 1916, 3. Band, 10. Heft.

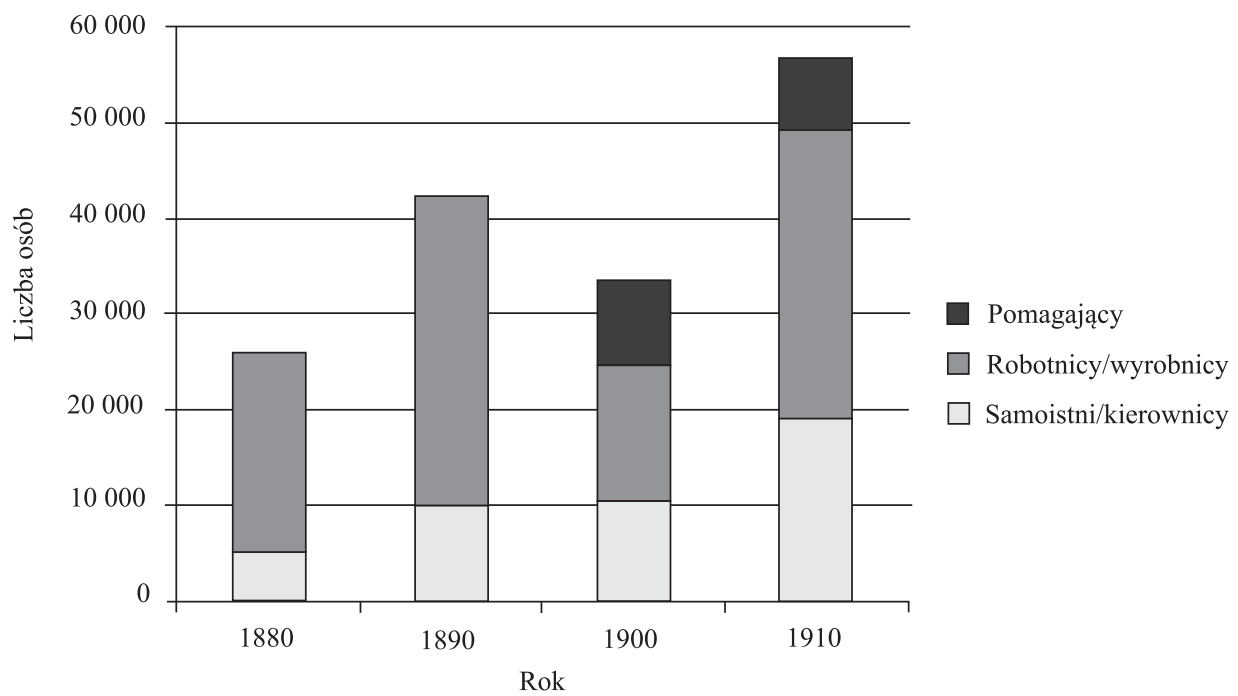

Wykres 5. Kobiety pracujące w sektorze rzemieślniczo-przemysłowym w latach 1880-1910 według sposobu zarobkowania

Źródło: obliczenia własne na podstawie: RSPHK 1888, z. 11; OS 1894, 33. Band, 11. Heft; OS 1904, 66. Band, 11. Heft; OS.NF 1916, 3. Band, 10. Heft. 
Poza wąską ofertą ze strony gospodarki galicyjskiej kształt struktury zatrudnienia w sektorze 2 mógł być w pewnym stopniu uwarunkowany czynnikami mentalnościowymi. Przykład Galicji staje się doskonałą ilustracją tego, co wielokrotnie podkreślali historycy dostrzegający długotrwałe zakorzenienie się tradycyjnego modelu pojmowania aktywności ekonomicznej kobiety, w którym takie specjalizacje, jak właśnie praca przy produkcji odzieży, nie obniżały jej statusu społecznego. Tu bowiem wykorzystywano ,przyrodzone” kwalifikacje, szczególnie cenione przy wyrobie artykułów luksusowych ${ }^{29}$. Charakter tej wytwórczości nie kłócił się z poglądami konserwatywnego społeczeństwa. Nie jest przecież kwestią przypadku, że wśród zawodów rękodzielniczych dla kobiet wyodrębnionych w Galicji ustawowo w 1907 roku znajdujemy hafciarstwo złotem, hafciarstwo srebrem i perłami, wyrób pościeli, krawiectwo, rękawicznictwo i bandażownictwo, kapelusznictwo, modniarstwo, wyrób sztucznych kwiatów, introligatorstwo ${ }^{30}$. Te najbardziej popularne spośród nich gałęzie rzemiosła mogły reprezentować, i prawdopodobnie reprezentowały, model produkcji manufakturowej, słabo zmechanizowanej. Brak przemysłu fabrycznego wpychał kobiety w obszar przemysłu domowego realizującego się również w ramach uznanej za anachroniczną w rozwoju rynku pracy - rodzinnej wspólnoty gospodarczej. W tym kierunku ewoluowało ich zatrudnienie, osiągając apogeum w 1910 roku.

Słabe zróżnicowanie struktury zawodowej kobiet może też świadczyć o tym, że dla większości z nich, pochodzących z małych miasteczek i obszarów wiejskich, a zwłaszcza migrujących ze wsi do miast, sektor ten nie stanowił wystarczającej alternatywy. Fala kobiet, którą zarejestrowały statystyki z 1910 roku w branży odzieżowej, tworzyła najczęściej jednoosobowe warsztaty czy pracownie krawieckie o charakterze chałupniczym, który nie zmieniał modelu pracy kobiecej w sposób tak ostry jak na przykład przemysł włókienniczy. O ile w roku 1880 na jedną kobietę samodzielną lub kierującą przysłowiowym warsztatem rzemieślniczym przypadały cztery robotnice, a w 1890 - trzy, o tyle w 1900 i 1910 roku było to statystycznie odpowiednio 1,4 i 1,6 kobiety. W 1910 roku liczba samodzielnych kobiet pracodawców wzrosła 3,7 razy w stosunku do 1880 roku, a robotnic tylko półtrora raza (zob. wykres 5).

Brak koncentracji oraz wyraźna tendencja do dominacji jednej gałęzi gospodarki raczej wyklucza (przynajmniej na prowincji) postrzeganie struktury zawodowej kobiet w 1910 roku jako czegoś nowego ${ }^{31}$. Wiele wskazuje na to, że w sektorze rzemieślniczo-przemysłowym przekształcenia świadczące o przełamywaniu tradycyjnego modelu pracy kobiet były obserwowalne w niewielkim obszarze i przebiegały bardzo powoli. Nie można mimo to całkowicie ich zanegować. Spotykamy

29 A. Żarnowska, Kierunki aktywności zawodowej kobiet w Polsce XX wieku (do 1939 r.) [w:] Kobieta i edukacja na ziemiach polskich $w$ XIX i XX w. Zbiór studiów. Cz. 2, red. A. Żarnowska, A. Szwarc, Warszawa 1992, s. 162-163.

30 W. Najdu s, op. cit., s. 244-245; Sz. Kozak, Kobieta w Galicji w ramach austriackiego prawa cywilnego, „Prace Historyczno-Archiwalne” 2006, t. 17, 61-83.

31 Por. L. Biliński, O pracy kobiet ze stanowiska ekonomicznego, „Przewodnik Naukowy i Literacki” 1874 , t. 2, s. 24-46. 
przecież kobiety w gałęziach typowo przemysłowych - co potwierdzają badania Andrzeja Burzyńskiego ${ }^{32} \mathrm{w}$ sektorze przemysłu ciężkiego, czy choćby w przemyśle tytoniowym (gdzie w latach 80. i 90. pracowało ponad 3 tys. kobiet w roli robotników - a żeński personel przeważa $1^{33}$ ). Jednakże udział ten nie był na tyle znaczący, by wpłynąć na obraz ogólny. Zjawisko masowego wejścia kobiet na rynek włókienniczy znane z Królestwa Polskiego w początkach lat 80. nie miało swojego odpowiednika w warunkach galicyjskich. Nawet w najbardziej dynamicznym dziale odzieżowym w proporcji do mężczyzn ich liczebność w latach 1890-1910 wahała się od jednej czwartej do jednej trzeciej.

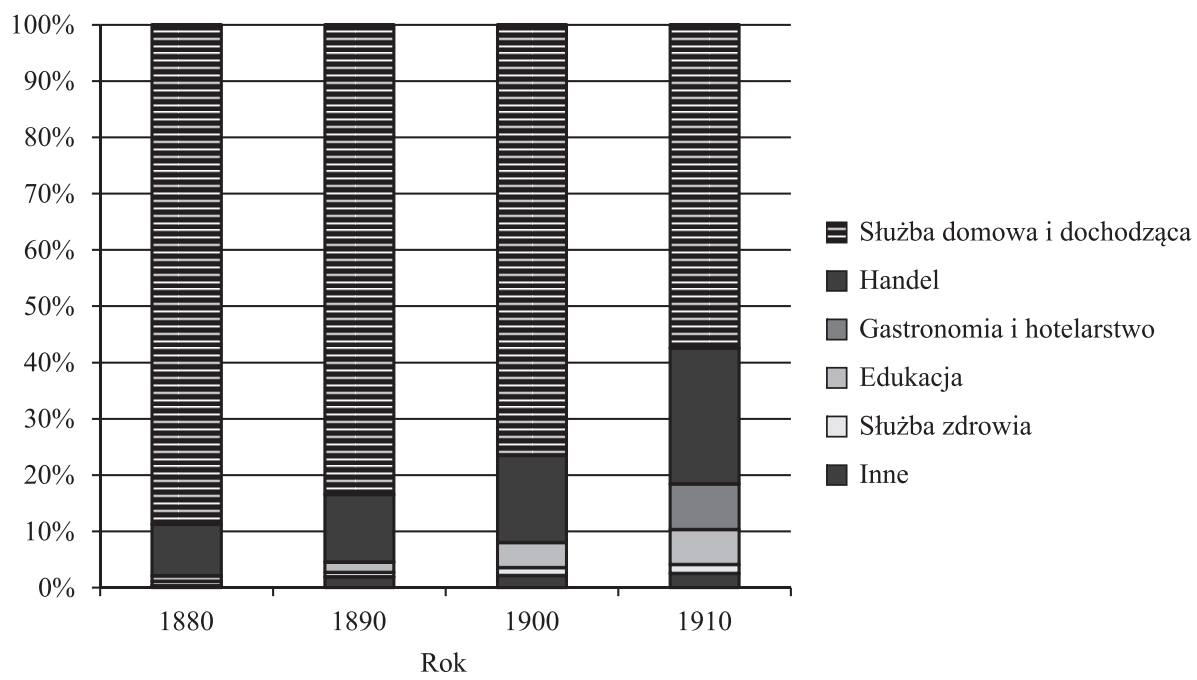

Wykres 6. Struktura zatrudnienia kobiet w sektorze 3 w latach 1880-1910

Źródło: obliczenia własne na podstawie: RSPHK 1988, z. 11; OS 1894, 33. Band, 11. Heft; OS 1904, 66. Band, 11. Heft; OS.NF 1916, 3. Band, 10. Heft.

Inaczej kształtowała się sytuacja w sektorze 3. Również i tutaj widzimy wyraźnie spolaryzowaną strukturę zatrudnienia, z niewielkim zróżnicowaniem i przewagą jednego działu, w tym wypadku służby domowej i dochodzącej (wykres 6). W dziale tym w 1880 roku było zatrudnionych do $90 \%$ kobiet z całego sektora, ale jego popularność malała i w 1910 roku spadła poniżej 60\%. Spadek ten wyraził się zresztą nie tylko proporcjonalnie. Liczba kobiet utrzymujących się z pracy służącej zmniejszyła się w stosunku do 1880 roku o 20\%. Można się zastanawiać, w jakim stopniu zjawisko to świadczyło o trwałej tendencji. Wszak przez długi czas była to i tak najliczniejsza forma zarobkowania, w dodatku jej popularność utrzymała się na wysokim

32 Por. A. Burzyński, Robotnicy w przemyśle ciężkim, passim.

33 Por. „Rocznik Statystyki Galicji”, R. 3 (1889-1891), Lwów 1891; Podręcznik Statystyki Galicji, t. 6, cz. 2, Lwów 1901; Podręcznik Statystyki Galicji, t. 9, cz. 2, Lwów 1913. 
poziomie jeszcze w latach 30. XX wieku ${ }^{34}$. W 1910 roku nie traktowano jej już jednak jako wyłącznej alternatywy nawet dla kobiet bez kwalifikacji zawodowych pochodzących ze spauperyzowanych środowisk. Zważywszy na zbliżone źródła rekrutacji, konkurencję dla tej niezbyt perspektywicznej formy zarobkowania mogła stanowić emigracja. Jest to tym bardziej prawdopodobne, że według danych biur pośrednictwa pracy z 1911 roku popyt na służbę domową dwukrotnie przewyższał podaż ${ }^{35}$.

W ciągu 30 lat dał się też zauważyć wzrost znaczenia pozostałych gałęzi, co najlepiej oddaje dynamika zmian w sektorze 3. W stosunku do 1880 roku liczba kobiet zatrudnionych wzrosła: w służbie zdrowia o $188 \%$ (głównie dotyczyło to niższego personelu medycznego), w handlu o $225 \%$, a w sektorze edukacji (jako nauczycielki różnych stopni szkolnictwa) aż o $682 \%$. Innym przykładem ewolucji galicyjskiego rynku pracy kobiet może być administracja publiczna (bez wyznaniowej) i zawody urzędnicze, gdzie liczba zatrudnionych wzrosła w omawianym okresie dwudziestokrotnie! Można by więc odnieść wrażenie, że poza rolnictwem to właśnie sektor 3 stwarzał największe szanse na zdobycie zatrudnienia przez kobiety.

Polska specyfika kobiecego rynku pracy, również poza Galicją, miała faworyzować gałęzie pozaprzemysłowe $\mathrm{z}$ handlem, służbą publiczną, usługami czy najbardziej chłonnym rolnictwem na czele ${ }^{36}$. Podobnie jak praca chałupnicza stanowiły one doraźne uzupełnienie utrzymania do czasu zamążpójścia, a niekiedy dłużej. Kontynuacja takiego stylu życia zależała od pozycji ekonomicznej oraz tego, czy ów styl nie naruszał zasad panujących $w$ rodzinie patriarchalnej ${ }^{37}$. Ciekawych informacji dostarcza analiza tego zjawiska przez pryzmat struktury wyznaniowej (wykres 7-8).

Szczególnie na tym tle wyróżnia się społeczność żydowska stanowiąca w 1910 roku ponad 10\% mieszkańców Galicji. Jeszcze przed I wojną światową aktywność zawodową przejawiała zaledwie jedna czwarta kobiet z tej grupy, czyli połowę mniej niż w przypadku pozostałych wyznań. Ponieważ dane spisowe były zbyt ogólne (umożliwiały porównanie jedynie w odniesieniu do czterech głównych działów gospodarki), nie można było ich standaryzować za pomocą metody PST, zachowano więc oryginalny podział. Również i w tym przypadku struktura ich zatrudnienia zdecydowanie się różniła. Dominowały w niej handel i komunikacja, zatrudniające prawie połowę aktywnych zawodowo (zob. wykres 8).

Aktywizacja kobiet na galicyjskim rynku pracy była mimo to zjawiskiem bezspornym. W ciągu 30 lat od 1880 roku ich liczba we wszystkich sektorach łącznie wzrosła o ponad jedną trzecią w tempie, jakie nie ustępowało aktywizacji mężczyzn. Spośród niezarobkujących w 1900 roku aż trzy czwarte to dziewczęta, które nie przekroczyły 10. roku życia. Jeśli zauważymy, że współcześnie wskaźnik aktywności zawodowej kobiet w Polsce wynosi ponad 48\% (dane za lata 2012-2015) ${ }^{38}$, to wynik zbliżony do $70 \%$, jaki w 1900 roku charakteryzował zabór austriacki, staje się bardzo

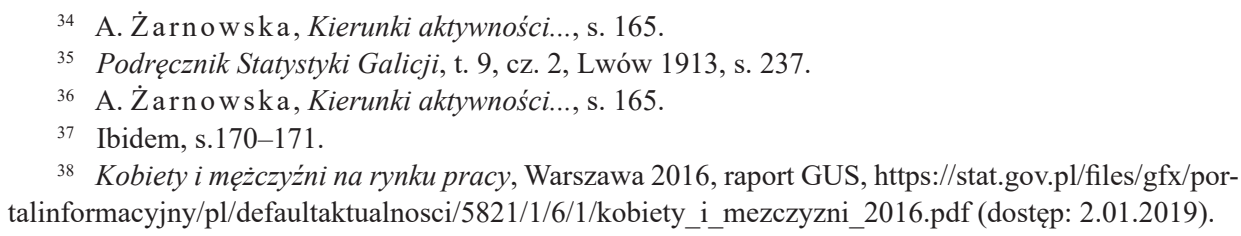

38 Kobiety i mężczyźni na rynku pracy, Warszawa 2016, raport GUS, https://stat.gov.pl/files/gfx/portalinformacyjny/pl/defaultaktualnosci/5821/1/6/1/kobiety_i_mezczyzni_2016.pdf (dostęp: 2.01.2019). 


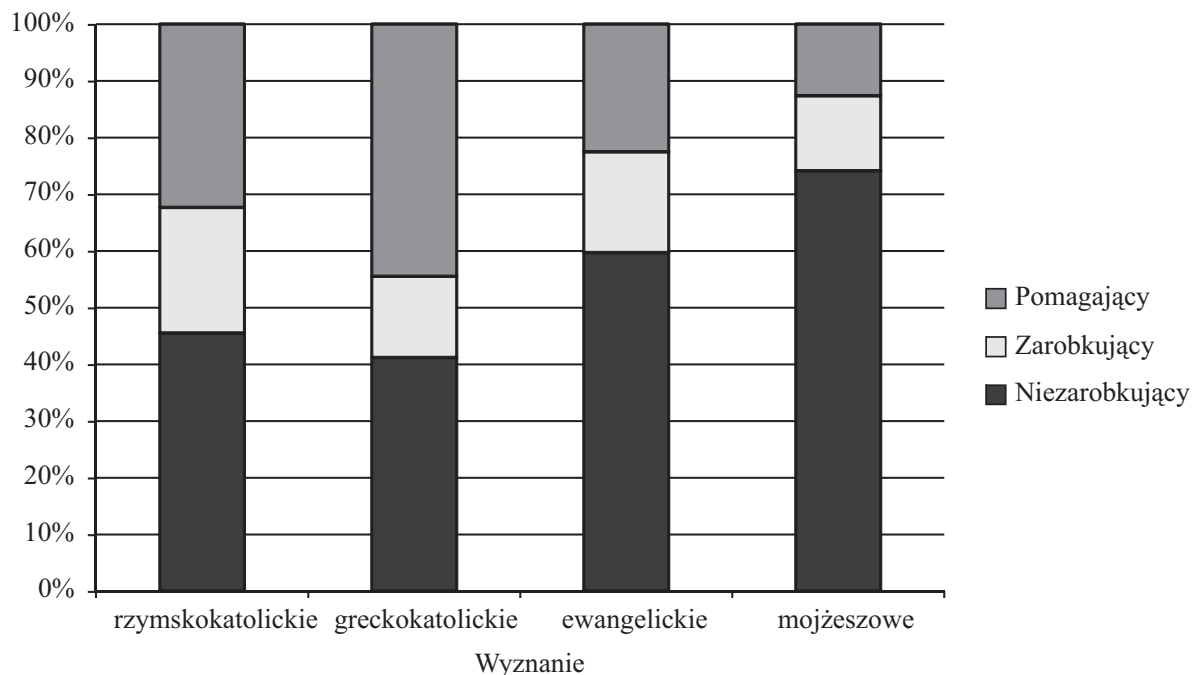

Wykres 7. Kobiety w Galicji pod względem aktywności zawodowej w 1910 r. (wg głównych wyznań)

Źródło: OS.NF 1916, 3. Band, 10. Heft, s. 225.

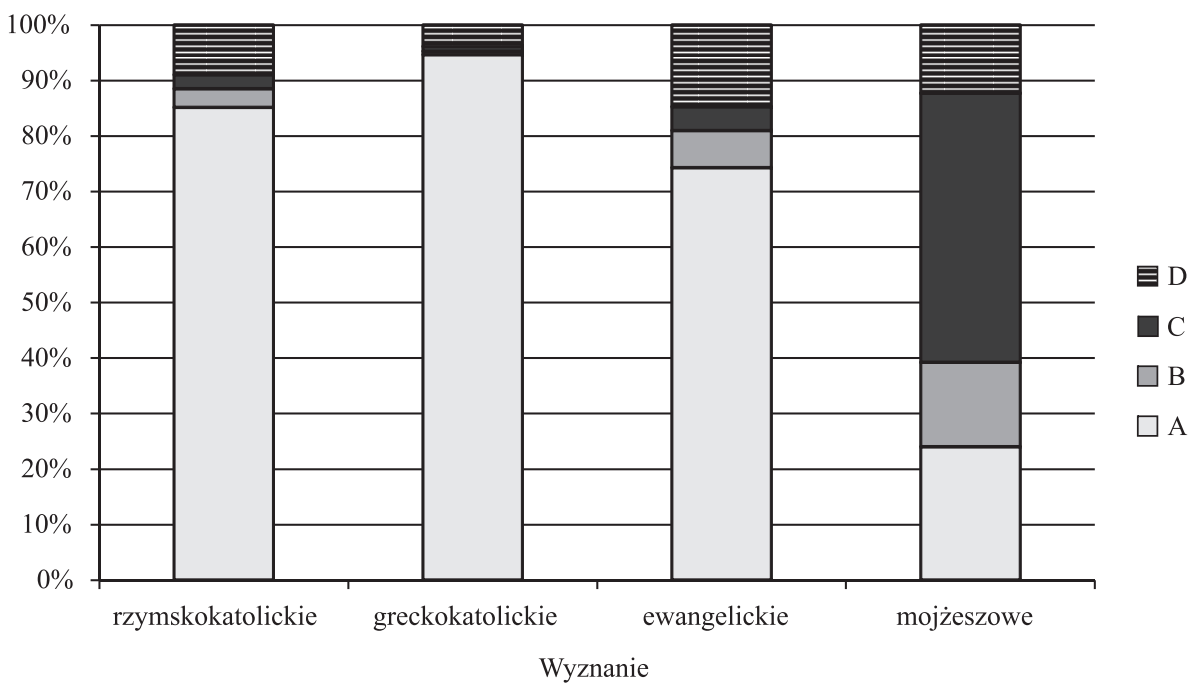

Wykres 8. Struktura zatrudnienia kobiet w 1910 r. wg wyznania i głównych klas zawodowych (bez służby domowej)

Objaśnienia: A - rolnictwo i leśnictwo; B - przemysł; C - handel i komunikacja; D - służba publiczna, wojsko, wolne zawody 
wymowny. Należy jednak zwrócić uwagę, że porównania takie z uwagi na dystans dzielący obie zbiorowości powinniśmy traktować z dużą ostrożnościąa ${ }^{39}$ Ponadto w XIX wieku forma tej aktywności była w większości archaiczna i wiązała się raczej z pracą zarobkową niż zawodową (po wyeliminowaniu pomagających członków rodziny wskaźnik aktywności zawodowej wyniósł $20 \%$ ). Jej ton nadawało rolnictwo ze wszystkimi tego konsekwencjami. Jeśli uwzględnić korektę dokonaną dla roku 1880, liczba kobiet tak zatrudnionych wzrosła z ponad 1200000 do około 1800000 w 1910 roku. Ten sektor charakteryzował się równocześnie najniższym ich udziałem na stanowiskach samodzielnych/kierowników gospodarstw, wynosząc odpowiednio 9\% (1880), 6\% (1890), 6\% (1900), 12\% (1910); oraz bardzo wysokim - pomagających członków rodziny - na poziomie 81\% (1900) i 78\% (1910).

Dynamika zatrudnienia w sektorach pozarolniczych była skrajnie zróżnicowana, przekraczając w przemyśle z rzemiosłem $100 \%$, a w pozostałych zaledwie $18 \%$. Niewielki udział osób zatrudnionych poza rolnictwem - na poziomie 11-13\% - znacznie ograniczał zasięg tych przewartościowań. Przy niskim uprzemysłowieniu w zasadzie liczył się tylko sektor 3 .

Pewnym odniesieniem wskazującym na charakter aktywizacji zawodowej może być relacja między osobami zatrudnionymi oraz pomagającymi członkami rodziny, której w poprzednich analizach nie uwzględniono całościowo. Anna Żarnowska traktuje występowanie w społeczeństwie XIX-wiecznym zjawiska „rodzinnej wspólnoty gospodarczej" jako przykład anachronizmu w kształtowaniu się rynku pracy ${ }^{40}$. Stąd skala partycypacji w nim kobiet wydaje się dobrym miernikiem ich pozycji zawodowej. Porównanie takie pozwoli ponadto na urealnienie szacunku rzeczywiście zatrudnionych. Z przyczyn opisanych już wyżej możliwości takiego badania ograniczone są do dwóch ostatnich spisów powszechnych.

W latach 1900-1910 zatrudnienie kobiet w roli pomagających członków rodziny było bardzo duże. Po pominięciu grup nieproduktywnych wynosiło odpowiednio 74\% (1900) i 70\% (1910) w proporcji do zarobkujących (jedynie u Żydów proporcje były bardziej wyrównane). Choć ów nieznaczny spadek (o 4 pkt proc.) nie wyraził się w liczbach bezwzględnych (faktycznie ich liczba wzrosła w tej grupie w ciągu 10 lat o ok. 10\%), to jednak szybciej powiększała się liczba kobiet zarobkujących (o ok. 40\%). Był to więc trend korzystny.

W poszczególnych sektorach wielkości te różniły się dość zasadniczo. Jak wiemy, $\mathrm{w}$ rolnictwie udział kobiet pomagających $\mathrm{w}$ proporcji do zatrudnionych charakteryzowała tendencja zbliżona do ogólnej, ale na wyższym poziomie. W pozostałych wynosił on odpowiednio 26\% (1900) i 13\% (1910) w sektorze 2 oraz 8\% (1900) i $20 \%$ (1910) w sektorze 3. Wśród męskiej części społeczeństwa galicyjskiego proporcje te wyglądały inaczej. Udział pomagających w tym samym okresie był u mężczyzn niższy i wahał się nieznacznie w granicach jednej czwartej. Ich liczba rosła jednak

39 Do podobnych wniosków dochodzi L.A. Zyblikiewicz. Szerzej zob. eadem, Ludność Krakowa ..., s. 245-246.

40 A. Żarnowska, Praca zarobkowa kobiet $i$ ich aspiracje zawodowe $w$ środowisku robotniczym i inteligenckim na przełomie XIX i XX wieku [w:] Kobieta i praca. Wiek XIX i XX. Zbiór studiów. T. 6, red. A. Żarnowska, A. Szwarc, Warszawa 2000, s. 42. 
szybciej (ok. 20\%). Mniej dynamicznie wzrastała natomiast liczba rzeczywiście zatrudnionych - o około $10 \%$.

Trudno w takim wypadku oprzeć się wrażeniu, że praca kobiet ciągle nosiła w Galicji charakter pomocniczy, nawet pomimo tego, że w sektorach pozarolniczych zjawisko to przyjmowało łagodniejsze, choć i tak niejednolite, rozmiary. Dobrym przykładem może być handel, gdzie w latach 1900-1910 liczba kobiet posiadających status pomagającego członka rodziny wzrosła z 50\% do około $64 \%$, niewiele ustępując rolnictwu.

Jeszcze ostrzej wyrazi się kwestia aktywizacji zawodowej, jeśli spojrzymy na nią przez pryzmat osób uznanych za zarobkujące (z pominięciem pomagających oraz grup nieproduktywnych). W proporcji do całej subpopulacji kobiet ich udział wynosił 12\% w 1900 i 15\% w 1910 roku. Wcześniej musiał być jeszcze mniejszy, choć ustalenie jego rozmiarów wydaje się problematyczne. Co prawda Bogusława Czajecka szacuje, że zarobkujące liczyły w 1890 roku 368000 czyli 11\% ogółu, ale nie popiera tego żadnym przypisem ${ }^{41}$. Przyjmując mimo wszystko te wielkości, można na podstawie szczegółowej analizy liczebności poszczególnych kategorii zawodowych oszacować, że rozmiary rzeczywistego zatrudnienia kobiet jeszcze w 1880 roku wahały się między 300000 a 330000 (wynosząc ok. 10\%). Należy jednak zaznaczyć, że w obu tych przypadkach są to wielkości czysto teoretyczne.

Taka specyfika pracy bardzo utrudnia odniesienia do współczesności. Podstawy do rewizji poczynionych nieco wyżej optymistycznych założeń dostarczyło jednak spojrzenie na Galicję przez pryzmat innych ziem polskich czy austriackich krajów koronnych. W pierwszym przypadku wykorzystano rezultaty badań opublikowanych w tekście P. Korysia i M. Tymińskiego ${ }^{42}$. Z zamieszczonego tam wykresu wynika, że dla przełomu XIX i XX wieku ${ }^{43}$ sytuacja zawodowa kobiet na obszarze trzech galicyjskich izb handlowych (Lwów, Kraków, Brody) na tle Królestwa Polskiego nie była niczym wyjątkowym. Podobny kształt struktury PST miały gubernie: suwalska, siedlecka, radomska, łomżyńska, lubelska oraz kielecka w Królestwie Polskim. Nie było jednak w Galicji przysłowiowych lokomotyw, jak gubernia warszawska i piotrkowska, które windowały udział kobiet zatrudnionych w sektorach pozarolniczych na poziom odpowiednio 48 i 43\%. Na terenie zaboru pruskiego rolę taką odgrywała rejencja gdańska $(41 \%)^{44}$. Nie można w takich kategoriach traktować pojedynczych miast galicyjskich, jak Kraków i Lwów, choć niewątpliwie zajmowały one czołową pozycję ${ }^{45}$. Nie przełożył się na sytuację zawodową kobiet boom naftowy. Jeśli w latach 1902-1911 przy wydobyciu ropy zatrudnienie znajdowało rocznie od 5 do ponad 6 tysięcy mężczyzn, udział kobiet wahał się przeważnie w granicach 3-5 osób ${ }^{46}$ !

${ }^{41}$ B. Czajecka, op. cit., s. 152.

42 P. Koryś, M. Tymiński, op. cit.

43 Ibidem, s. 156 (wykres 8).

44 Ibidem.

45 Por. L.A. Zyblikiewicz, Aktywność zawodowa...

46 Podręcznik Statystyki Galicji, t. 9, cz. 2, Lwów 1913, s. 207. Zatrudnienie kobiet przy wydobyciu ropy naftowej wynosiło w kolejnych latach: $1902-5,1903-5,1904-27,1905-16,1906-3,1907-4$, $1908-4,1909-4,1910-4,1911-3$. 
Dla porównania kopalnie węgla kamiennego zatrudniały w tym samym okresie ponad 100 kobiet rocznie ${ }^{47}$.

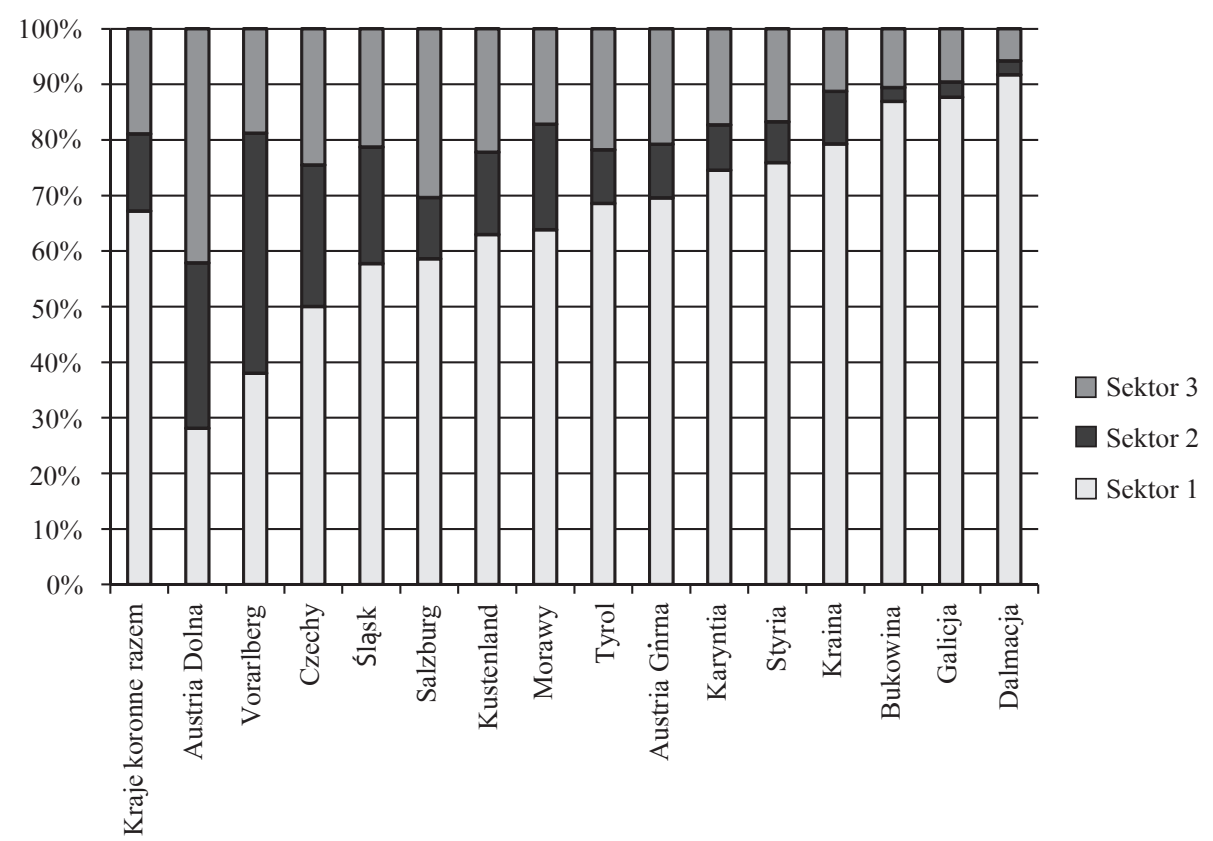

Wykres 9. Główne obszary aktywności zawodowej kobiet w austriackich krajach koronnych w $1910 \mathrm{r}$.

Źródło: OS.NF 1914, 3. Band, 2. Heft (Niederösterreich); OS.NF 1914, 3. Band, 3. Heft (Oberösterreich und Salzburg); OS.NF 1915, 3. Band, 4. Heft (Steiermark); OS.NF 1915, 3. Band, 5. Heft (Kärnten und Krain); OS.NF 1915, 3. Band, 6. Heft (Küstenland und Dalmatien); OS.NF 1915, 3. Band, 7. Heft (Tirol und Vorarlberg); OS.NF 1916, 3. Band, 8. Heft (Böhmen); OS.NF 1916, 3. Band, 9. Heft (Mähren und Schlesien); OS.NF 1916, 3. Band, 10. Heft (Galizien und Bukowina). 


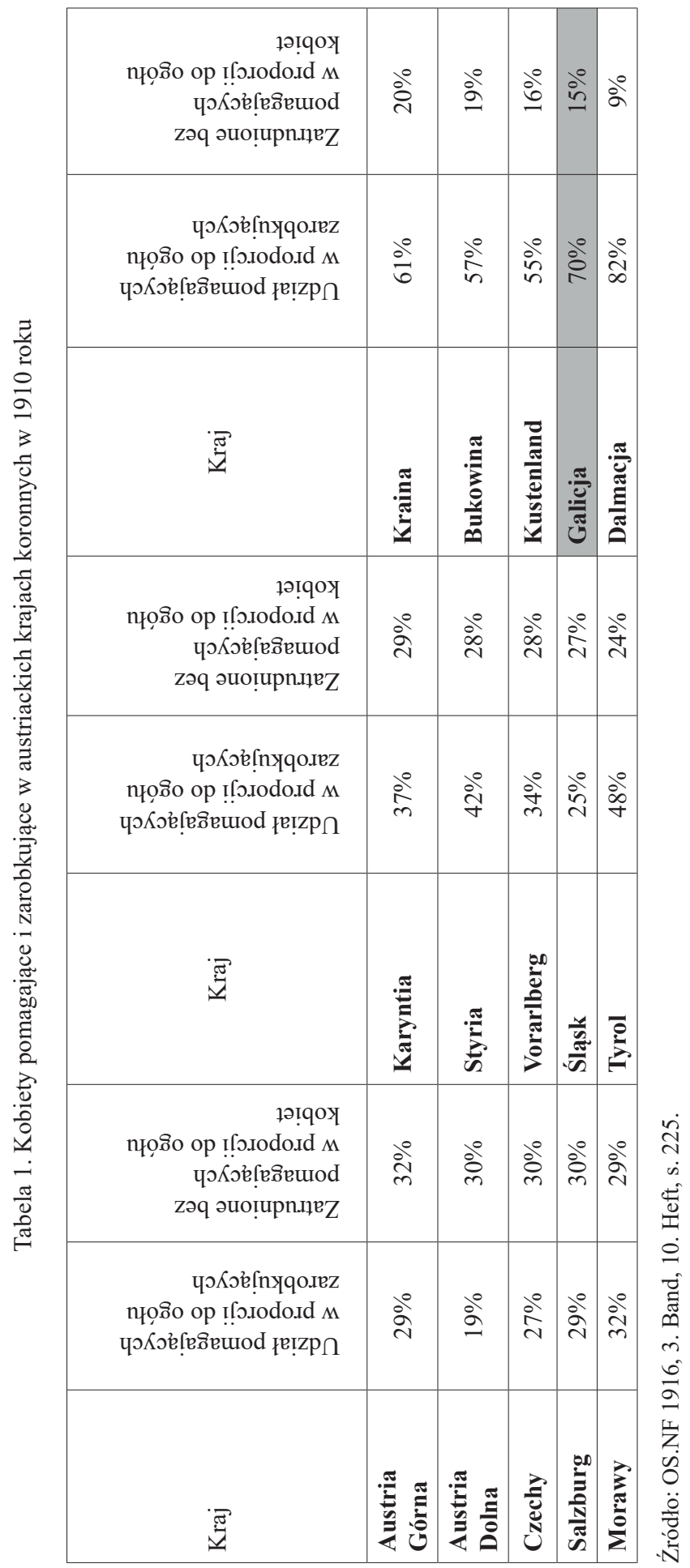


Większy dystans widać w porównaniu z niektórymi austriackimi krajami koronnymi dziesięć lat później, w 1910 roku (wykres 9). Kształt struktury PST wyraźnie przesuwa Galicję w stronę krajów o minimalnym znaczeniu sektorów pozarolniczych, jak Bukowina czy Dalmacja. W kształtowaniu rynku pracy kobiet zamieszkujących znaczną część obszarów monarchii austriackiej sektory te odgrywały jednak aż trzykrotnie większą rolę, a w niektórych ich udział przekraczał 50\% (Austria Dolna, Vorarlberg, Czechy). Podobne spostrzeżenia dotyczą charakteru ich pracy (tabela 1). Przy około 30-procentowym poziomie zatrudnienia jako siły pomocniczej, charakterystycznym dla krajów położonych w centrum i na zachodzie, widoczna staje się różnica między nimi a Galicją. Nawet na Bukowinie wskaźnik ten okazał się korzystniejszy. Taki sam obraz peryferyjności wyłania się po uwzględnieniu w analizie osób uznanych za zatrudnione. W większości krajów koronnych ich udział był dwukrotnie większy. Choć pozornie główne kierunki ewolucji struktury zawodowej kobiet nie odbiegały zasadniczo od ogólnych trendów występujących na innych ziemiach polskich, tu mamy do czynienia z ich mniej korzystnym wariantem.

Aktywizacja we współczesnym tego słowa znaczeniu, której synonimem jest profesjonalizacja, specjalizacja i w rezultacie samorealizacja zawodowa, nie była w Galicji przed I wojną światową jeszcze zjawiskiem powszechnym. Inaczej sytuowały się pod tym względem duże miasta (z Krakowem i Lwowem na czele), inaczej prowincja. Dla większości kobiet aktywność na rynku pracy, choć bezdyskusyjna, bardziej wiązała się z koniecznością ekonomiczną niż z aspiracjami zawodowymi. Jej oblicze stanowiło tu - poza rolnictwem - chałupnictwo, handel, służba domowa i emigracja zarobkowa. Gdyby poszukiwać symptomów zapowiadających nadejście nowoczesności, to dają się one zaobserwować w obrębie raczej wąskiej grupy. Jej reprezentantki występują za to licznie w literaturze naukowej, publicystyce czy beletrystyce $-z$ jednej strony jako rodzaj awangardy, z drugiej jako osobliwość wykraczająca poza ramy przewidziane tradycją. Obok nauczycielek i akuszerek coraz częściej są to subiektki, pracownice urzędów pocztowych, biur, przedstawicielki świata kultury i sztuki, a nawet prowadzące samodzielną działalność gospodarczą.

$\mathrm{O}$ ile początek XX wieku zastał kobiety w roli aktywnych uczestniczek rynku pracy, o tyle głębsze zmiany w ich sytuacji zawodowej musiała wyprzedzić rzeczywistość I wojny światowej. Problematyka ta wymaga jednak głębszych badań. 


\section{ANEKS}

Tabela 2. Kobiety w Galicji według grup zawodowych i sposobu zarobkowania w $1880 \mathrm{r}$.

\begin{tabular}{|c|c|c|c|c|}
\hline Grupy zawodowe & Samoistni & $\begin{array}{l}\text { Urzędnicy, } \\
\text { kierownicy } \\
\quad \text { itp. }\end{array}$ & Robotnicy & $\begin{array}{l}\text { Służba } \\
\text { domowa }\end{array}$ \\
\hline Duchowni wszystkich wyznań & 1291 & 68 & 603 & 5292 \\
\hline $\begin{array}{l}\text { Urzędnicy czynni w służbie dworu, } \\
\text { państwa, kraju, powiatu lub gminy }\end{array}$ & 83 & 0 & 0 & 5587 \\
\hline Wojskowi czynni & 0 & 0 & 0 & 602 \\
\hline Nauczyciele & 1520 & 0 & 0 & 2830 \\
\hline Literaci i redaktorzy & 4 & 0 & 7 & 79 \\
\hline $\begin{array}{l}\text { Aktorzy, śpiewacy, muzycy } \\
\text { i tancerze }\end{array}$ & 128 & 0 & 0 & 177 \\
\hline Malarze i rzeźbiarze & 2 & 0 & 7 & 96 \\
\hline $\begin{array}{l}\text { Architekci, inżynierowie cywilni } \\
\text { i geometrzy }\end{array}$ & 0 & 0 & 4 & 350 \\
\hline Adwokaci i notariusze & 0 & 0 & 6 & 756 \\
\hline $\begin{array}{l}\text { Lekarze i osoby w wyższym } \\
\text { zawodzie medycznym }\end{array}$ & 12 & 0 & 24 & 1096 \\
\hline $\begin{array}{l}\text { Osoby w niższym zawodzie } \\
\text { medycznym }\end{array}$ & 930 & 31 & 60 & 323 \\
\hline Służba czynna przy urzędach & 15 & 0 & 0 & 749 \\
\hline $\begin{array}{l}\text { Żandarmeria, straż bezpieczeństwa, } \\
\text { straż finansowa i inne organy } \\
\text { publicznego nadzoru i straży }\end{array}$ & 0 & 0 & 0 & 910 \\
\hline $\begin{array}{l}\text { Rolnictwo i leśnictwo z pobocznymi } \\
\text { zajęciami - właściciele }\end{array}$ & 110632 & 648 & 778184 & 68745 \\
\hline $\begin{array}{l}\text { Rolnictwo i leśnictwo z pobocznymi } \\
\text { zajęciami - dzierżawcy } \\
\text { i czynszownicy }\end{array}$ & 681 & 121 & 5687 & 4645 \\
\hline Rybołówstwo morskie & 0 & 0 & 0 & 0 \\
\hline Górnictwo i hutnictwo & 10 & 4 & 1398 & 694 \\
\hline $\begin{array}{l}\text { Przemysł i rękodzieło - wielki } \\
\text { i mały }\end{array}$ & 4623 & 575 & 20817 & 13938 \\
\hline Handel hurtowy i detaliczny & 4983 & 642 & 8638 & 10970 \\
\hline $\begin{array}{l}\text { Instytucje bankowe i kredytowe, } \\
\text { bankierzy }\end{array}$ & 24 & 5 & 2 & 723 \\
\hline $\begin{array}{l}\text { Środki komunikacji lądowej } \\
\text { (przewóz osób i towarów) }\end{array}$ & 107 & 46 & 182 & 2025 \\
\hline
\end{tabular}




\begin{tabular}{|l|r|r|r|r|}
\hline $\begin{array}{l}\text { Środki komunikacji wodnej } \\
\text { (przewóz osób i towarów) }\end{array}$ & 1 & 0 & 17 & 25 \\
\hline Właściciele domów i rentierzy & 7670 & 58 & 0 & 7372 \\
\hline Pensjonariusze & 2897 & 0 & 0 & 1886 \\
\hline $\begin{array}{l}\text { Zakłady naukowe, wychowawcze } \\
\text { i naukowe, zakłady sierot }\end{array}$ & 48 & 40 & 57 & 177 \\
\hline Zakłady dobroczynne i humanitarne & 138 & 29 & 41 & 174 \\
\hline $\begin{array}{l}\text { Służba niemieszkająca } \\
\text { u służbodawcy }\end{array}$ & 0 & 0 & 0 & 5697 \\
\hline $\begin{array}{l}\text { Robotnicy dzienni ze zmiennym } \\
\text { zatrudnieniem }\end{array}$ & 0 & 0 & 101727 & 1584 \\
\hline Osoby niewiadomego zatrudnienia & 3164 & 0 & 0 & 388 \\
\hline RAZEM & 138963 & 2267 & 917461 & 137890 \\
\hline
\end{tabular}

Źródło: RSPHK 1888, z. 11, s. 2-9.

Tabela 3. Kobiety w Galicji według grup zawodowych i sposobu zarobkowania w $1890 \mathrm{r}$.

\begin{tabular}{|l|r|r|r|r|r|}
\hline \multicolumn{1}{|c|}{ Grupy zawodowe } & Samoistni & $\begin{array}{l}\text { Urzędnicy, } \\
\text { kierownicy } \\
\text { itp. }\end{array}$ & Robotnicy & Wyrobnicy & $\begin{array}{c}\text { Służba } \\
\text { domowa }\end{array}$ \\
\hline $\begin{array}{l}\text { Rolnictwo, hodowla zwierząt, } \\
\text { ogrodnictwo }\end{array}$ & 93860 & 350 & 1407571 & 97112 & 9524 \\
\hline Leśnictwo i pokrewne & 15 & 25 & 1014 & 81 & 1335 \\
\hline Rybołówstwo i kultura wodna & 5 & 0 & 17 & 3 & 31 \\
\hline Górnictwo i hutnictwo & 41 & 7 & 1224 & 604 & 686 \\
\hline Przemysł kamieniarski i ziemny & 66 & 5 & 515 & 216 & 413 \\
\hline Przerób metali z wyjątkiem żelaza & 19 & 3 & 89 & 4 & 328 \\
\hline Przerób żelaza i stali & 134 & 5 & 885 & 36 & 1000 \\
\hline $\begin{array}{l}\text { Wyrób maszyn narzędzi } \\
\text { i instrumentów }\end{array}$ & 37 & 4 & 281 & 21 & 494 \\
\hline Przemysł chemiczny & 55 & 2 & 225 & 47 & 734 \\
\hline Przemysł budowlany & 174 & 6 & 1118 & 151 & 1892 \\
\hline Poligrafia & 18 & 5 & 137 & 3 & 201 \\
\hline Przemysł tkacki i przędzalnictwo & 328 & 11 & 2212 & 167 & 625 \\
\hline Przemysł skórzany i papiernictwo & 63 & 3 & 497 & 51 & 645 \\
\hline Przemysł drzewny & 183 & 9 & 1008 & 171 & 1405 \\
\hline Wyrób artykułów spożywczych & 891 & 16 & 3179 & 106 & 5038 \\
\hline
\end{tabular}




\begin{tabular}{|l|r|r|r|r|r|}
\hline $\begin{array}{l}\text { Wyrób napojów, zakłady gościnne } \\
\text { itp.. }\end{array}$ & 1561 & 41 & 9563 & 377 & 8145 \\
\hline Wyrób odzieży & 6498 & 12 & 9872 & 681 & 5745 \\
\hline $\begin{array}{l}\text { Zatrudnieni w przemyśle bez } \\
\text { bliższego określenia }\end{array}$ & 12 & 4 & 634 & 79 & 164 \\
\hline Handel towarowy & 6184 & 377 & 11411 & 302 & 22720 \\
\hline Handel pieniężny, ubezpieczenia & 50 & 24 & 37 & 0 & 934 \\
\hline Komunikacja lądowa & 151 & 369 & 940 & 162 & 4991 \\
\hline Komunikacja wodna & 57 & 2 & 52 & 18 & 84 \\
\hline Inny handel & 3939 & 29 & 2281 & 27935 & 7160 \\
\hline Armia czynna & 0 & 0 & 0 & 0 & 968 \\
\hline $\begin{array}{l}\text { Urzędnicy państwowi, krajowi, } \\
\text { gminni }\end{array}$ & 1923 & 3769 & 1794 & 33 & 17773 \\
\hline Wolne zawody & 232 & 103 & 141 & 6 & 1248 \\
\hline Rentierzy & 19170 & 42 & 968 & 116 & 6289 \\
\hline Pozostający w zakładach itp. & 10382 & 0 & 0 & 0 & 0 \\
\hline $\begin{array}{l}\text { Samoistni bez podania miejsca } \\
\text { zatrudnienia }\end{array}$ & 8111 & 0 & 0 & 0 & 1846 \\
\hline RAZEM & 154159 & 5223 & 1457665 & 128482 & 102418 \\
\hline
\end{tabular}

Źródło: OS 1894, 33. Band, 11. Heft, s. 138-139.

Tabela 4. Kobiety w Galicji według grup zawodowych i sposobu zarobkowania w $1900 \mathrm{r}$.

\begin{tabular}{|l|r|r|r|r|r|r|}
\hline \multicolumn{1}{|c|}{ Grupy zawodowe } & Samoistni & $\begin{array}{l}\text { Urzędnicy, } \\
\text { kierownicy } \\
\text { itp. }\end{array}$ & Robotnicy & Wyrobnicy & $\begin{array}{c}\text { Służba } \\
\text { domowa }\end{array}$ & Pomagający \\
\hline $\begin{array}{l}\text { Rolnictwo, } \\
\text { hodowla zwierząt, } \\
\text { ogrodnictwo }\end{array}$ & 99063 & 151 & 76273 & 135527 & 12790 & 1295012 \\
\hline Leśnictwo i pokrewne & 8 & 9 & 345 & 236 & 1189 & 145 \\
\hline $\begin{array}{l}\text { Rybołówstwo } \\
\text { i kultura wodna }\end{array}$ & 3 & 0 & 13 & 0 & 8 & 3 \\
\hline $\begin{array}{l}\text { Górnictwo } \\
\text { i hutnictwo }\end{array}$ & 10 & 7 & 294 & 83 & 675 & 33 \\
\hline $\begin{array}{l}\text { Przemysł } \\
\text { kamieniarski i ziemny }\end{array}$ & 89 & 2 & 273 & 70 & 408 & 126 \\
\hline Przerób metali-1 & 8 & 0 & 198 & 36 & 937 & 165 \\
\hline Przerób metali - & 24 & 1 & 67 & 9 & 0 & 3 \\
\hline $\begin{array}{l}\text { Wyrób maszyn } \\
\text { narzędzi } \\
\text { i instrumentów }\end{array}$ & & 2 & 19 & 527 & 49 \\
\hline
\end{tabular}




\begin{tabular}{|c|c|c|c|c|c|c|}
\hline Przemysł chemiczny & 30 & 6 & 203 & 60 & 906 & 51 \\
\hline Przemysł budowlany & 150 & 10 & 395 & 118 & 1859 & 148 \\
\hline Poligrafia & 18 & 5 & 185 & 1 & 263 & 14 \\
\hline $\begin{array}{l}\text { Przemysł tkacki } \\
\text { i przędzalnictwo }\end{array}$ & 390 & 10 & 1350 & 258 & 331 & 345 \\
\hline $\begin{array}{l}\text { Przemysł skórzany } \\
\text { i papierniczy }\end{array}$ & 59 & 4 & 380 & 62 & 302 & 47 \\
\hline Przemysł drzewny & 209 & 5 & 701 & 123 & 822 & 222 \\
\hline $\begin{array}{l}\text { Wyrób artykułów } \\
\text { spożywczych }\end{array}$ & 771 & 15 & 519 & 30 & 2372 & 1338 \\
\hline $\begin{array}{l}\text { Wyrób napojów, } \\
\text { zakłady gościnne itp. }\end{array}$ & 2063 & 35 & 2971 & 336 & 4767 & 5293 \\
\hline Wyrób odzieży & 6483 & 8 & 5267 & 449 & 1664 & 1077 \\
\hline $\begin{array}{l}\text { Zatrudnieni } \\
\text { w przemyśle bez } \\
\text { bliższego określenia }\end{array}$ & 23 & 2 & 71 & 41 & 57 & 12 \\
\hline Handel towarowy & 8064 & 103 & 1426 & 135 & 11407 & 9562 \\
\hline $\begin{array}{l}\text { Handel pieniężny, } \\
\text { ubezpieczenia }\end{array}$ & 41 & 98 & 17 & 2 & 1600 & 16 \\
\hline Komunikacja lądowa & 174 & 717 & 275 & 46 & 5176 & 121 \\
\hline Komunikacja wodna & 20 & 1 & 16 & 8 & 29 & 9 \\
\hline $\begin{array}{l}\text { Inne przedsiębiorstwa } \\
\text { handlowe } \\
\text { i komunikacyjne }\end{array}$ & 302 & 4 & 51 & 51 & 869 & 74 \\
\hline $\begin{array}{l}\text { Służba dochodząca } \\
\text { i zarobnicy } \\
\text { o zmiennym zajęciu }\end{array}$ & 3618 & 0 & 397 & 14632 & 938 & 191 \\
\hline Armia czynna & 0 & 0 & 0 & 0 & 1446 & 0 \\
\hline $\begin{array}{l}\text { Urzędnicy } \\
\text { państwowi, krajowi, } \\
\text { gminni }\end{array}$ & 2928 & 7843 & 752 & 22 & 18219 & 86 \\
\hline Wolne zawody & 513 & 184 & 75 & 1 & 880 & 37 \\
\hline Rentierzy & 21309 & 0 & 0 & 0 & 6099 & 0 \\
\hline $\begin{array}{l}\text { Pozostający } \\
\text { w zakładach }\end{array}$ & 14582 & 0 & 0 & 0 & 0 & 0 \\
\hline $\begin{array}{l}\text { Samoistni bez } \\
\text { podania miejsca } \\
\text { zatrudnienia }\end{array}$ & 13774 & 0 & 0 & 0 & 2328 & 0 \\
\hline RAZEM & 174774 & 9222 & 92533 & 152336 & 78868 & 1314179 \\
\hline
\end{tabular}

Źródło: OS 1904, 66. Band, 11. Heft, s. 97-98. 


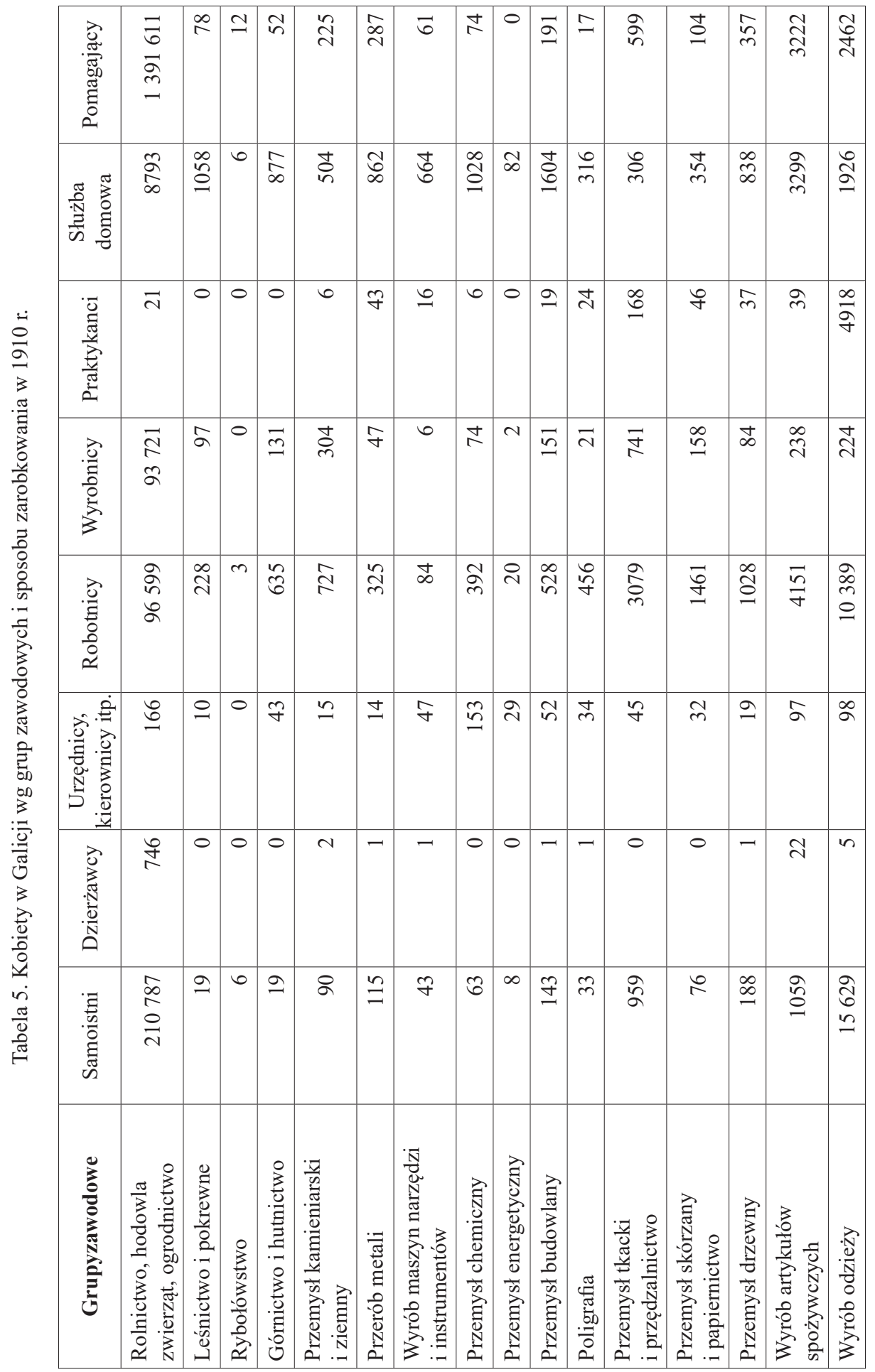




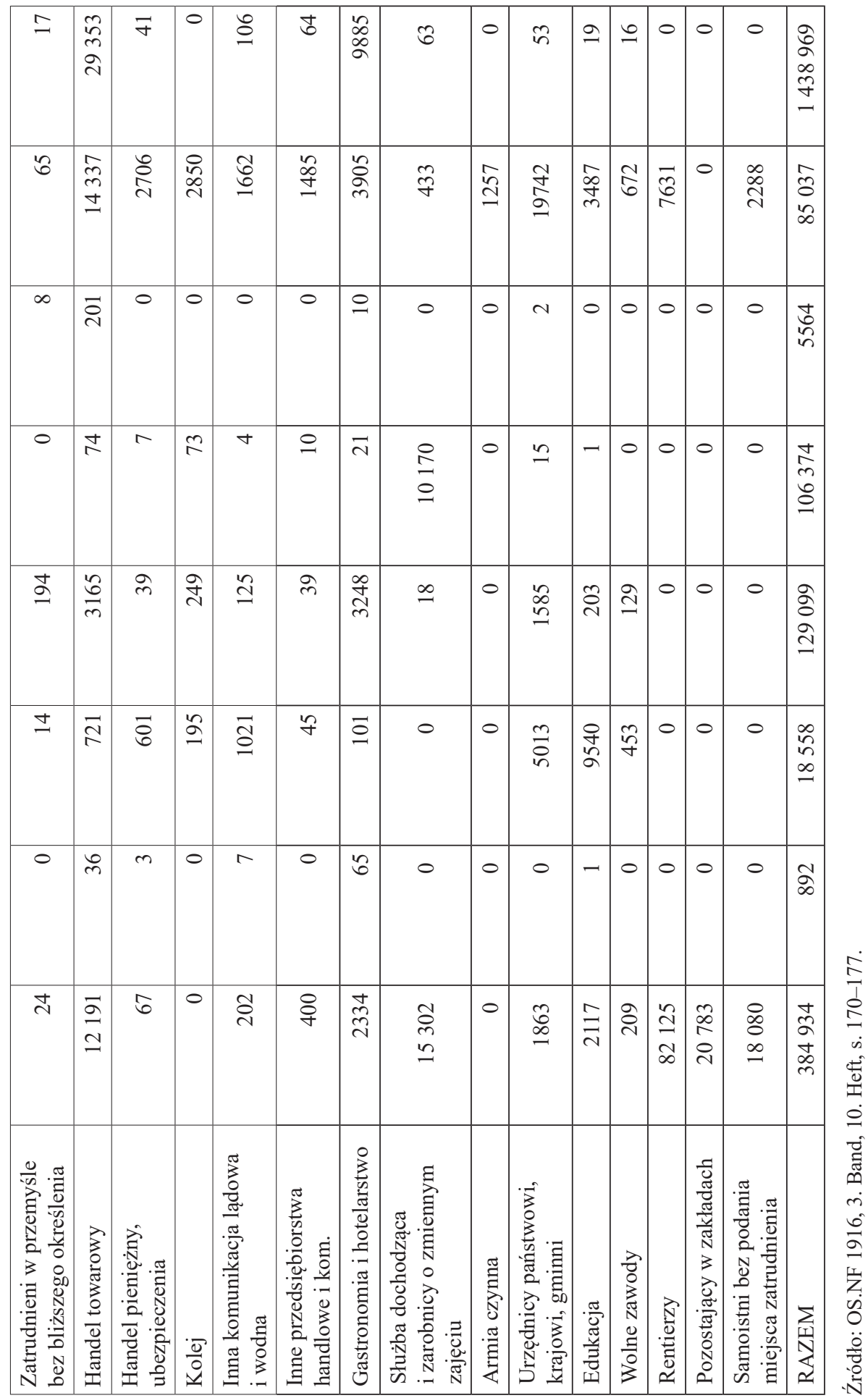




\section{BIBLIOGRAFIA}

\section{Źródła}

Podręcznik Statystyki Galicji, t. 6, cz. 2, Lwów 1901.

Podręcznik Statystyki Galicji, t. 8, cz. 2, Lwów 1908.

Podręcznik Statystyki Galicji, t. 9, cz. 2, Lwów 1913.

„Österreichische Statistik” (Wien) 1894, 33. Band, 11. Heft.

„Österreichische Statistik” (Wien) 1904, 66. Band, 11. Heft.

„Österreichische Statistik. Neue Folge” (Wien) 1916, 3. Band, 10. Heft.

„Österreichische Statistik. Neue Folge” (Wien) 1914, 3. Band, 2. Heft (Niederösterreich).

„Österreichische Statistik. Neue Folge” (Wien) 1914, 3. Band, 3. Heft (Oberösterreich und Salzburg).

„Österreichische Statistik. Neue Folge” (Wien) 1915, 3. Band, 4. Heft (Steiermark).

„Österreichische Statistik. Neue Folge” (Wien) 1915, 3. Band, 5. Heft (Kärnten und Krain).

„Österreichische Statistik. Neue Folge” (Wien) 1915, 3. Band, 6. Heft (Küstenland und Dalmatien).

„Österreichische Statistik. Neue Folge” (Wien) 1915, 3. Band, 7. Heft (Tirol und Vorarlberg).

„Österreichische Statistik. Neue Folge” (Wien) 1916, 3. Band, 8. Heft (Böhmen).

„Österreichische Statistik. Neue Folge” (Wien) 1916, 3. Band, 9. Heft (Mähren und Schlesien).

„Rocznik Statystyki Galicji”, R. 3 (1889-1891), Lwów 1891.

„Rocznik Statystyki Przemysłu i Handlu Krajowego”, z. 11, Lwów 1888.

„Rocznik Statystyczny Pracy”, Warszawa 2015.

\section{Opracowania}

Baidak M., Between society and house: The history of the emancipation of the Ukrainian women of Eastern Galicia during the First World War, „Res Gestae. Czasopismo Historyczne" 2016, nr 3, s. 194-235. DOI: 10.24917/24504475.3.8.

Baidak M., Жінка в Галичині в умовах першої світової війни у світлі порівняльних студій [w:] Kobieta w Galicji. Nowoczesność i tradycja, red. J. Kamińska-Kwak, Sz. Kozak, D. Opaliński, Rzeszów 2016, s. 494-507.

Biliński L., O pracy kobiet ze stanowiska ekonomicznego, „Przewodnik Naukowy i Literacki" 1874, t. 2, s. 24-46.

Broński K., Galicja w dobie autonomii wobec wyzwań nowoczesności [w:] Między zacofaniem a modernizacja. Społeczno-gospodarcze problemy ziem polskich na przestrzeni wieków, red. E. Kościk, T. Głowiński, Wrocław 2009, s. 395-412.

Broński K., Rozwój gospodarczy większych miast galicyjskich w okresie autonomii, Kraków 2003, s. 89-98.

Broński K., Struktura społeczno-zawodowa oraz sytuacja ekonomiczna ludności większych miast galicyjskich dobie autonomii (1867-1914), „Zeszyty Naukowe Akademii Ekonomicznej w Krakowie" 2003, nr 638, s. 5-20.

Bujak F., Galicja, t. 1, Warszawa 1908. 
Burzyński A., Robotnicy w przemyśle ciężkim w Galicji w dobie autonomicznej. Struktura zatrudnienia, Wrocław [etc.] 1985.

Burzyński A., Statystyka austriacka i krajowa jako źródło do badań nad struktura społeczno-zawodowa zatrudnionych w przemyśle ciężkim w Galicji, „Studia Historyczne” 1983, R. 26, z. 2 (101), s. 223-242.

Burzyński A., Z rozważań nad ocena austriackich powszechnych spisów ludności z lat 1869-1919, „Przeszłość Demograficzna Polski” 1984, t. 15, s. 58-69.

Czajecka B., Z domu w szeroki świat. Droga kobiet do niezależności w zaborze austriackim w latach 1890-1914, Kraków 1990.

Czerczowycz I., Realizacja zawodowa kobiet końca XIX-początku XX w. na przykładzie społeczeństwa ukraińskiego w Galicji, „Przegląd Nauk Historycznych” 2014, nr 13 (2), s. $147-161$.

Czerczowycz I., Społeczna wizja życia codziennego kobiety Ukrainki we Lwowie na przetomie XIX i XX wieku [w:] Lwów. Miasto - społeczeństwo - kultura, t. 9: Życie codzienne miasta, red. K. Karolczak, Ł.T. Sroka, Kraków 2014, s. 244-254.

Czerczowycz I., Ukrainki w Galicji Wschodniej w drugiej połowie XIX - na początku XX wieku Między tradycyjnymi wartościami rodzinnymi a wyzwaniami emancypacji [w:] Obrazy kobiecości. Zbiór studiów, red. M. Jabłoński, B. Koperski, J. Falla, W. Pilch, M. Hohenauer, Kraków 2014, s. 227-242.

Czerczowycz I., „Zdrowa, niemoralna, bez najmniejszego wykształcenia”. Kobiety w sprawach karnych na podstawie dokumentów Sąu Krajowego we Lwowie (druga potowa XIX-początek XX wieku) [w:] Kobieta w Galicji. Nowoczesność i tradycja, red. J. Kamińska-Kwak, Sz. Kozak, D. Opaliński, Rzeszów 2016, s. 100-109.

Galicja i jej dziedzictwo, t. 24: Kobieta w Galicji. Nowoczesność i tradycja, red. J. Kamińska-Kwak, Sz. Kozak, D. Opaliński, Rzeszów 2016.

Gąsowski T., Austriackie spisy ludności z lat 1869-1910, „Przeszłość Demograficzna Polski" 1981, t. 13, s. 37-48.

Gąsowski T., Struktura społeczno-zawodowa mieszkańców większych miast galicyjskich w okresie autonomicznym, „Prace Historyczne. ZNUJ” 1997, z. 123, s. 113-135.

Hanusyn O., ,,Inteligentna kobieta nasza czuła się jednocześnie Rusinka i mężczyzna”. Wątki kobiece w ksztattowaniu się ukraińskiej inteligencji $w$ dziewiętnastowiecznej Galicji [w:] Kobieta w Galicji. Nowoczesność i tradycja, red. J. Kamińska-Kwak, Sz. Kozak, D. Opaliński, Rzeszów 2016, s. 110-120.

Kłapkowska J., Struktura zawodowa ludności Galicji w erze autonomicznej, „Prace Prawnicze. ZNUJ" 1975, nr 70, s. 115-131.

Kobiety i mężczyźni na rynku pracy, Warszawa 2016, raport GUS, https://stat.gov.pl/files/ gfx/portalinformacyjny/pl/defaultaktualnosci/5821/1/6/1/kobiety_i_mezczyzni_2016. pdf (dostęp: 2.01.2019).

Колб Н., Роль жінки (матері / дружини) в житті греко-католицького парафіяльного духовенства в Галичині наприкінці XIX - на початку XX століття (на прикладі о. Ісидора Глинського) [w:] Kobieta w Galicji. Nowoczesność i tradycja, red. J. Kamińska-Kwak, Sz. Kozak, D. Opaliński, Rzeszów 2016, s. 195-209.

Kordzikowska J., Sytuacja społeczno-zawodowa kobiety w Rzeszowie pod koniec XIX wie$k u$, mps rozprawy doktorskiej, Rzeszów 2012.

Koryś P., Tymiński M., Struktura zawodowa ziem polskich na przełomie XIX i XX w., „Roczniki Dziejów Społecznych i Gospodarczych” 2015, t. 75, s. 129-166. 
Kozak Sz., Aktywność gospodarcza kobiet w Galicji w świetle Skorowidza przemysłowo-handlowego z 1912 roku. Zarys problematyki, „Studia z Historii Społeczno-Gospodarczej XIX i XX wieku" 2014, t. 13, s. 81-95.

Kozak Sz., Kobieta na prowincji galicyjskiej w świetle akt notarialnych 1871-1914. Studium historyczno-źródłoznawcze, Rzeszów 2013.

Kozak Sz., Kobieta w Galicji w ramach austriackiego prawa cywilnego, „Prace Historyczno-Archiwalne" 2006, t. 17, s. 61-83.

Kozak Sz., Kobiety w życiu gospodarczym Galicji. Stan i perspektywy badań [w:] Region i regionalizm $w$ archeologii $i$ historii, red. J. Hoff, S. Kadrow, Rzeszów 2013, s. 174 183.

Kulczykowski M., Modernizacja społeczeństwa galicyjskiego w warunkach autonomii politycznej [w:] Samomodernizacja spoleczeństw w XIX wieku. Irlandczycy, Czesi, Polacy, red. L. Trzeciakowski, K. Makowski, Poznań 1999, s. 107-129.

Najdus W., Zmiany społeczno-ekonomicznej pozycji kobiety $w$ galicyjskim środowisku drobnomieszczańskim [w:] Kobieta i edukacja na ziemiach polskich w XIX i XX w. Zbiór studiów. Cz. 2, red. A. Żarnowska, A. Szwarc, Warszawa 1992, s. 237-256.

Орлевич I., Жіноче питання у трактуванні русофілів (за сторінками періодичного видання «Временникь Ставропигійскаго Института») [w:] Kobieta w Galicji. Nowoczesność i tradycja, red. J. Kamińska-Kwak, Sz. Kozak, D. Opaliński, Rzeszów 2016, s. 57-72.

Tomczyk R., Rusinki (Ukrainki) w austriackiej Galicji. Pomiędzy konserwatyzmem a radykalizmem, „Przegląd Zachodniopomorski” 2012, nr 2, s. 89-111.

Zamorski K., Informator statystyczny do dziejów spoleczno-gospodarczych Galicji. Ludność Galicji w latach 1857-1910, Kraków-Warszawa 1989.

Zyblikiewicz L.A., Aktywność zawodowa kobiet w Krakowie w II połowie XIX wieku, „Przeszłość Demograficzna Polski” 2015, t. 37, nr 4, s. 83-103.

Zyblikiewicz L.A., Kobieta w Krakowie z 1880 r. w świetle ankiet powszechnego spisu ludności. Studium demograficzne, Kraków 1999.

Zyblikiewicz L.A. Ludność Krakowa $w$ drugiej połowie XIX wieku. Struktura demograficzna, zawodowa i społeczna, Kraków 2014.

Zyblikiewicz L.A., Powszechne spisy ludności w monarchii Habsburgów [w:] Celem nauki jest człowiek... Studia z historii społecznej i gospodarczej ofiarowane Helenie Madurowicz-Urbańskiej, red. nauk. P. Franaszek, Kraków 2000, s. 387-400.

Żarnowska A., Kierunki aktywności zawodowej kobiet w Polsce XX wieku (do 1939 r.) [w:] Kobieta i edukacja na ziemiach polskich w XIX i XX w. Zbiór studiów. Cz. 2, red. A. Żarnowska, A. Szwarc, Warszawa 1992, s. 162-163.

Żarnowska A., Kierunki ewolucji struktury społeczno-zawodowej na ziemiach polskich i jej odmienności dzielnicowe w końcu XIX i na początku XX w. [w:] Drogi integracji społeczeństwa $w$ Polsce XIX-XX w., red. H. Zieliński, Wrocław [etc.] 1976, s. 139-150.

Żarnowska A., Zmiany struktury społeczno-zawodowej ludności ziem polskich na tle Europy Środkowej [w:] Gospodarka przemystowa i początki cywilizacji technicznej. Studia i materiały, red. I. Pietrzak-Pawłowska, Wrocław 1977, s. 257-269.

Żarnowska A., Praca zarobkowa kobiet $i$ ich aspiracje zawodowe w środowisku robotniczym i inteligenckim na przetomie XIX $i$ XX wieku [w:] Kobieta i praca. Wiek XIX i XX. Zbiór studiów. T. 6, red. A. Żarnowska, A. Szwarc, Warszawa 2000, s. $29-52$. 